medRxiv preprint doi: https://doi.org/10.1101/2021.10.05.21264462; this version posted October 7, 2021. The copyright holder for this preprint (which was not certified by peer review) is the author/funder, who has granted medRxiv a license to display the preprint in It is made available under a CC-BY-NC-ND 4.0 International license .

\title{
Detection and quantification of SARS-CoV-2 RNA in wastewater influent in relation to reported COVID-19 incidence in Finland
}

\author{
Ananda Tiwari ${ }^{1,2 \#}$, Anssi Lipponen ${ }^{1 \#}$, Anna-Maria Hokajärvi ${ }^{1 \#}$, Oskari Luomala ${ }^{3}$, Anniina \\ Sarekoski $^{1}$, Annastiina Rytkönen ${ }^{1,2}$, Pamela Österlund ${ }^{4}$, Haider Al-Hello ${ }^{4}$, Aapo Juutinen ${ }^{3}$, \\ Ilkka T. Miettinen', Carita Savolainen-Kopra ${ }^{4}$, and Tarja Pitkänen1,2 *
}

${ }^{1}$ Finnish Institute for Health and Welfare, Expert Microbiology Unit, Neulaniementie 4, FI-70701 Kuopio, Finland, ananda.tiwari@thl.fi (AT), anssi.lipponen@thl.fi (AL), annamaria.hokajarvi@thl.fi (AH), anniina.sarekoski@thl.fi (AS), annastiina.rytkonen@thl.fi (AR), ilkka.miettinen@thl.fi (IM), tarja.pitkanen@thl.fi (TP)

${ }^{2}$ University of Helsinki, Faculty of Veterinary Medicine, Department of Food Hygiene and Environmental Health, Agnes Sjöbergin katu 2, FI-00014, Helsinki, Finland, ananda.tiwari@helsinki.fi, annastiina.rytkonen@helsinki.fi, tarja.m.pitkanen@helsinki.fi.

${ }^{3}$ Finnish Institute for Health and Welfare, Infectious Disease Control and Vaccinations Unit, Mannerheimintie 166, FI-00271 Helsinki, Finland, oskari.luomala@thl.fi (OL, AJ) ${ }^{4}$ Finnish Institute for Health and Welfare, Expert Microbiology Unit, Mannerheimintie 166, FI00271 Helsinki, Finland, carita.savolainen-kopra@ thl.fi (PO, HA, CSK)

\#The authors have contributed equally to the work. *Correspondence: Tarja Pitkänen, Telephone: +358 29524 6315, Email: tarja.pitkanen@thl.fi 
medRxiv preprint doi: https://doi.org/10.1101/2021.10.05.21264462; this version posted October 7, 2021. The copyright holder for this preprint (which was not certified by peer review) is the author/funder, who has granted medRxiv a license to display the preprint in It is made available under a CC-BY-NC-ND 4.0 International license .

\begin{abstract}
Wastewater-based surveillance is a cost-effective concept for monitoring COVID-19 pandemics at a population level. Here, SARS-CoV-2 RNA was monitored from a total of 693 wastewater (WW) influent samples from 28 wastewater treatment plants (WWTP, $\mathrm{N}=21-42$ samples per WWTP) in Finland from August 2020 to May 2021, covering WW of ca. 3.3 million inhabitants $(\sim 60 \%$ of the Finnish population). The relative quantity of SARS-CoV-2 RNA fragments in the 24h-composite samples was determined by using the ultrafiltration method followed by nucleic acid extraction and RT-qPCR assay targeted with N2-assay. SARS-CoV-2 RNA signals at each WWTP were compared over time to the numbers of new and confirmed COVID-19 cases in the sewer network area.
\end{abstract}

Over the 10-month surveillance period, the detection rate of SARS-CoV-2 RNA in WW was 79\% (including 6\% uncertain results), while only $24 \%$ of all samples exhibited gene copy (GC) numbers above the quantification limit. The range of the SARS-CoV-2 detection rate in WW varied from $33 \%$ (including 10\% uncertain results) in Pietarsaari to 100\% in Espoo. Only six out of 693 WW samples were positive with SARS-COV-2 RNA when the reported COVID-19 case number from the preceding 14 days was zero. Overall, the 14-day COVID-19 incidence was 7, 18 and 36 cases within the sewer network area when the probability to detect SARS-CoV-2 RNA in wastewater samples was 50\%, 75\% and 95\%, respectively. The quantification of SARS-CoV-2 GC required significantly more COVID-19 cases: the quantification rate was 50\%, 75\% and 95\% when the 14 day incidence was 110, 152 and 223 COVID-19 cases, respectively, per 100000 persons. Multiple linear regression confirmed the relationship between the COVID-19 incidence and the SARS-CoV2 GC quantified in WW at 15 out of 28 WWTPs (overall $\mathrm{R}^{2}=0.36, p<0.001$ ). At four of the 13 WWTPs where a significant relationship was not found, the GC of SARS-CoV-2 RNA remained below the quantification limit during the whole study period. In the five other WWTPs, the sewer coverage was less than $80 \%$ of the total population in the area and thus the COVID-19 cases may have been inhabitants from the areas not covered. 
medRxiv preprint doi: https://doi.org/10.1101/2021.10.05.21264462; this version posted October 7, 2021. The copyright holder for this preprint (which was not certified by peer review) is the author/funder, who has granted medRxiv a license to display the preprint in It is made available under a CC-BY-NC-ND 4.0 International license .

Based on the results obtained, WW-based surveillance of SARS-CoV-2 could be used as an indicator for local and national COVID-19 incidence trends. Importantly, the determination of SARS-CoV-2 RNA fragments from WW is a powerful and non-invasive public health surveillance measure, independent of possible changes in the clinical testing strategies or in the willingness of individuals to be tested for COVID-19.

Keywords: Community sewage, Coronavirus, National surveillance, RT-qPCR assay, Wastewaterbased epidemiology

\section{Introduction}

Wastewater-based epidemiology (WBE) has been used in areas with centralized sewage network systems for evaluating the circulation of etiological agents of communicable diseases such as hepatitis $\mathrm{C}$ virus, poliovirus, and antibiotic-resistant bacteria, consumption patterns of illegal drugs, nicotine, alcohol, and pharmaceuticals in communities (Gracia-Lor et al. 2017, Lorenzo and Picó 2019, Sims et al. 2020). Recently, WBE has been reported as a quick, sensitive, and cost-effective approach for monitoring the prevalence, trend, and circulation of coronavirus disease (COVID-19) pandemics at the population level (Medema et al. 2020a, Hart and Halden 2020, Ahmed et al. 2020, Sherchan et al. 2020, Wang et al. 2020, Gonzalez et al. 2020, Hillary et al. 2021, Rusiñol et al. 2021, Lundy et al. 2021), and as an early warning tool (Medema et al. 2020a, Wu et al. 2020a, Ahmed et al. 2021a).

During the COVID-19 pandemic in 2020-2021, the WBE approach has been used worldwide to complement the clinical (individual testing) surveillance approach (Ahmed et al. 2020, Kumar et al 2020, WHO 2020, Sherchan et al. 2020, Hokajärvi et al. 2021). Sometimes, WBE data can be more reliable than clinical data, as the clinical diagnostic capacity is limited mostly to the population 
medRxiv preprint doi: https://doi.org/10.1101/2021.10.05.21264462; this version posted October 7, 2021. The copyright holder for this preprint (which was not certified by peer review) is the author/funder, who has granted medRxiv a license to display the preprint in It is made available under a CC-BY-NC-ND 4.0 International license .

having symptoms or with a recent travel history (Wu et al. 2020a). Further, clinical data can be biased depending on various factors such as differences in patient testing strategies, and sometimes the unwillingness of people to be tested. In that respect, the WBE approach is more unbiased as it accounts for the viral load of all infected (i.e., symptomatic, asymptomatic, pre-symptomatic, and post-symptomatic) people within the sewer network area (Wu et al. 2020b, Cevik et al. 2021, Wölfel et al. 2020).

The WBE approach to monitoring COVID-19 is an area of rapid development and thus all the factors defining the minimum threshold number of new COVID-19 cases within a sewer network area for detecting SARS-CoV-2 in the influent WW are not clear. One of the necessary considerations from the clinical standpoint is the variability in shedding quantities (viral load) and secretion routes (feces, urine, cough, sneeze, and sputum) of infected individuals from where virus particles end up in the sewage systems (Wölfel et al. 2020, Wang et al. 2020, Wu et al. 2020, Cevik et al. 2021). From the environmental standpoint, the fate and decay of SARS-CoV-2 in sewer networks and transit after sampling before analysis are not fully known (Hart and Halden 2020). Further, runoff waters and industrial WW might dilute SARS-CoV-2 quantities, and therefore various normalization procedures of SARS-CoV-2 copy numbers in WW are used; most often in the form of flow and population size normalization, but microbial indicators of human fecal loads have also been proposed (Medema et al. 2020a, 2020b, Green et al. 2020). Overall, a better understanding of the relationship between community COVID-19 incidence and SARS-CoV-2 GC in WW is needed for further development of the WBE approach.

Herein, this study compared a 10-month (August 2020 to May 2021) longitudinal monitoring of SARS-CoV-2 RNA in WW influent samples analyzed from 28 WWTPs in Finland with a 14-day COVID-19 case incidence rate (14-day moving sum, 14-DMS) of new and confirmed COVID-19 cases in the respective communities. The minimum number of COVID-19 cases needed in the respective communities for detecting and quantifying SARS-CoV-2 RNA in WW influent samples 
medRxiv preprint doi: https://doi.org/10.1101/2021.10.05.21264462; this version posted October 7, 2021. The copyright holder for this preprint (which was not certified by peer review) is the author/funder, who has granted medRxiv a license to display the preprint in It is made available under a CC-BY-NC-ND 4.0 International license .

in Finland was determined and the potential of WBE to catch the local and national COVID-19 incidence trends was investigated.

\section{Materials and Methods}

\subsection{Wastewater sample collection}

Between 3 August 2020 and 31 May 2021, a total of 693 influent WW samples were collected following the standard biosafety precautions for handling untreated WW as previously described (Hokajärvi et al. 2021). Samples were collected from 28 wastewater treatment plants (WWTPs) serving about 3.3 million inhabitants; this is about $60 \%$ of the total population of Finland.

Population coverage between the participating WWTPs varied from 860000 inhabitants in Helsinki to 18000 in Vihti, causing variability between WWTPs in the mean influent flow during the sampling events (Table 1). The mean WW influent inflow normalized per 100000 inhabitants was $29000 \mathrm{~m}^{3} /$ day during the 24-hour composite sampling events. A fraction ( 1 liter) of samples were transported in cool boxes as soon as possible to the Water Microbiology Laboratory of the Finnish Institute for Health and Welfare (THL), Kuopio, Finland, for analysis. As soon as the sample arrived at the laboratory, the arrival time and temperature were recorded, and the samples were stored at $+4{ }^{\circ} \mathrm{C}$ and mostly analyzed within $24-48$ hours.

The mean WW temperature was higher than $15^{\circ} \mathrm{C}$ after transit to the laboratory in August 2020 and a part of the samples also exceeded this temperature limit in September and October 2020. The arrival temperature was mostly below $15{ }^{\circ} \mathrm{C}$ from November 2020 to May 2021. The time in transit varied between one and two days depending on the location (Table 1). The time in transit was longer than two days only for nine out of 693 samples.

\subsection{Recording of the new COVID-19 cases in the WWTPs sewer network areas}

Throughout the study period, individual COVID-19 tests have been available for all symptomatic people in Finland. Clinical laboratories report all detected COVID-19 cases to the National 
medRxiv preprint doi: https://doi.org/10.1101/2021.10.05.21264462; this version posted October 7, 2021. The copyright holder for this preprint (which was not certified by peer review) is the author/funder, who has granted medRxiv a license to display the preprint in It is made available under a CC-BY-NC-ND 4.0 International license .

Infectious Disease Register (NIDR) detailing the total number of COVID-19 tests performed each day per each hospital district in Finland. The trend of daily reported cases of COVID-19 in the study sewer network areas during the study period shows increasing and decreasing trends (Figure $1)$.

For the purposes of comparing the clinical findings with the data produced by environmental monitoring of influent WW, the reported new COVID-19 cases in each municipality served by the 28 WWTPs were extracted from NIDR. Then the case numbers were corrected using a WWTPspecific factor corresponding to the share of inhabitants served by the sewer connected to the study WWTPs as compared to all inhabitants of the municipalities. This correction of the NIDR case numbers was necessary since each WWTP served one or more municipalities, and one municipality could have one or more WWTPs. Finally, the 14-DMS of the COVID-19 cases was calculated for each sewer network area. To compare with the WW data, the 14-day time window's end was set to the day of composite sampling. These moving sum COVID-19 case numbers were then normalized per 100000 population and we refer to these numbers as 14-day COVID-19 case incidence rate and in short 14-DMS.

\subsection{Determination of SARS-CoV-2 RNA fragments in the wastewater samples}

WW samples were analyzed as previously described (Hokajärvi et al. 2021). In brief, the ultrafiltration method (Medema et al., 2020) was used with the exception that $10 \mathrm{kDa}$ Centricon Plus-70 centrifugal filters were used for $70 \mathrm{ml}$ pre-centrifugated supernatants with a concentrationtime of 25 minutes in 3000 g producing $200 \mu 1-1600 \mu l$ of concentrate. Mengovirus and crAssphage were used as internal process controls (Pintó et al. 2009, Stachler et al. 2017). Sterile deionized water was used as negative process control.

For nucleic acid extraction from $300 \mu$ of the concentrate, and from $300 \mu \mathrm{lWW}$ without ultrafiltration, a Chemagic Viral300 DNA/RNA extraction kit was used with the Chemagic-360D 
medRxiv preprint doi: https://doi.org/10.1101/2021.10.05.21264462; this version posted October 7, 2021. The copyright holder for this preprint (which was not certified by peer review) is the author/funder, who has granted medRxiv a license to display the preprint in It is made available under a CC-BY-NC-ND 4.0 International license .

instrument (Perkin-Elmer, Germany). To verify the extraction performance, each extraction set included a positive swab sample (300 $\mu 1$ of 1:500 diluted, Ct approximately 29 after dilution, nasopharyngeal swab from a COVID-19 positive patient, dissolved into PBS and inactivated at $60^{\circ} \mathrm{C}$ for $\left.90 \mathrm{~min}\right)$ and a negative extraction control (300 $\mu 1$ sterile deionized water).

All RT-qPCR and qPCR assays were performed using QuantStudio 6 Flex real-time PCR system (Applied Biosystems, ThermoFisher Scientific). In addition to the negative ultrafiltration and nucleic acid extraction process controls, all runs included at least one reaction with moleculargrade water instead of nucleic acid (no template control, NTC). RT-qPCR assay targeting nucleocapsid (N) protein gene of SARS-CoV-2 was used (N2 assay; Lu et al. 2020). For samples taken between August 2020 and the end of January 2021, also a beta-coronavirus assay to detect the envelope (E) protein gene was used (E-Sarbeco assay; Corman et al. 2020). The reactions and the target quantification were carried out as described earlier (Hokajärvi et al. 2021) by using TaqMan Fast Virus 1-step Master Mix (Applied Biosystems, ThermoFisher Scientific). Non-diluted and 10fold diluted fractions of the extracted nucleic acid of each WW sample were analyzed in duplicates.

Mengovirus internal process control results to estimate the recovery efficiency and RT-qPCR inhibition were produced following the principles of international standard ISO/TS 15216-1:2013 (Pintó et al. 2009; Tables S2-S4). To characterize the fecal content of WW samples and further evaluation of the recovery efficiency of ultrafiltration, the cross-assembly phage (crAssphage) copy numbers were enumerated before and after ultrafiltration using a qPCR assay (Stachler et al. 2017). The total reaction volume of $25 \mu \mathrm{l}$ in crAssphage assay contained $5 \mu \mathrm{l}$ of nucleic acid template, primers in a final concentration of $1 \mu \mathrm{M}$, probe at concentration of $0.08 \mu \mathrm{M}$, and $12.5 \mu \mathrm{l}$ of Environmental Master Mix 2.0 (Applied Biosystems, ThermoFisher Scientific). Single, 10- and 100-fold dilutions of nucleic acid templates were used for qPCR analysis. The quantification of crAssphage was performed using a synthetic gene fragment containing primer annealing sites (Integrated DNA Technologies, Belgium) with eight standard points $10^{6}-10^{0} \mathrm{GC} / \mu 1$. 
medRxiv preprint doi: https://doi.org/10.1101/2021.10.05.21264462; this version posted October 7, 2021. The copyright holder for this preprint (which was not certified by peer review) is the author/funder, who has granted medRxiv a license to display the preprint in It is made available under a CC-BY-NC-ND 4.0 International license .

By using QuantiStudio Real-Time PCR System-software (Applied Biosystems, ThermoFisher Scientific), the reaction was considered successfully amplified when the $\mathrm{Ct}$ value was below 40 with a threshold in N2 0.1, E-Sarbeco 0.2, mengovirus 0.04, and crAssphage 0.05. The SARS-CoV2 results (N2 assay) were interpreted using four categories, as follows:

- Non-detected: when all out of four reactions (two undiluted and two 10-fold diluted nucleic acids as a template) did not have any amplification (i.e., $\mathrm{Ct}>40$ ).

- Uncertain: One out of four reactions had amplification with $\mathrm{Ct}<40$ but was not confirmed in repeated RT-qPCR analysis.

- Detected: when more than one RT-qPCR reaction was positive in the N2 assay but copy numbers were below the limit of quantification (LOQ; 50 GC per reaction).

- Detected and quantified: copy number of SARS-CoV-2 target per $100 \mathrm{ml}$ WW sample was calculated when the target was detected and the copy number exceeded the LOQ.

E-Sarbeco assay results were interpreted in the same categories as N2-assay, except copy numbers were not calculated. CrAssphage results were composed of arithmetic mean values of the two dilutions and reported as gene copy numbers per $100 \mathrm{ml}$ of WW sample.

The presence of inhibition was reported as a factor decreasing the reliability of the result if the difference in $\mathrm{Ct}$ values was more than two in the mengovirus assay between the nucleic acid templates from a sample and a negative process control. In $63 \%$ of the samples tested (433 samples out of 684) the presence of inhibitors was noted. As the inhibition was prevalent in WW nucleic acids based on the mengovirus control, no samples were excluded from the data due to the inhibition. However, for the N2 assay both un-diluted and 10-fold diluted and for crAssphage 10and 100-fold diluted nucleic acids were used to overcome the potential inhibitory effects in generating the results. 
medRxiv preprint doi: https://doi.org/10.1101/2021.10.05.21264462; this version posted October 7, 2021. The copyright holder for this preprint (which was not certified by peer review) is the author/funder, who has granted medRxiv a license to display the preprint in It is made available under a CC-BY-NC-ND 4.0 International license .

\subsection{Cell cultures to determine the viability of SARS-CoV-2 in the wastewater samples}

To determine the viability of SARS-CoV-2 in the WW samples using Vero E6 cell cultures, one WW influent sample collected at 10-11 May 2020 from WWTP in Helsinki and five WW influent samples collected at 18-19 October 2020 from WWTPs in Helsinki, Espoo, Vaasa, Jyväskylä, and Kouvola were used. Centricon concentrates were stored at $-20{ }^{\circ} \mathrm{C}$ with penicillin-streptomycingentamycin antibiotics (final concentration100 IU/ml, $500 \mu \mathrm{g} / \mathrm{ml}$ each) prior to analysis.

A Centricon concentrate ( $3.0 \mathrm{ml}$, equivalent to $84 \mathrm{ml}$ sample volume) obtained from the May 2020 sample was used (SARS-CoV-2 RNA copy number 11000 GC/100 ml, N2 assay). Vero E6 cell lines were cultivated in minimum essential medium (MEM) with 2\% fetal bovine serum (FBS), penicillin and streptomycin, and were incubated at $37{ }^{\circ} \mathrm{C}$ with $5 \% \mathrm{CO}_{2}$ for 7 days. The concentrate was inoculated in five Vero E6 cell culture flasks ( $0.5 \mathrm{ml}$ concentrate $/ 4.5 \mathrm{ml}$ MEM/flask). After the seventh day, the supernatant was filtered, and aliquots of $1.0 \mathrm{ml}$ cell culture supernatant was inoculated on two fresh cell flasks for the second passage as described above. To determine the viability of the virus, each day the flasks were examined under the light microscope and $250 \mu \mathrm{l}$ supernatant was collected for RNA extraction.

The SARS-CoV- 2 RNA copy numbers of the October 2020 concentrates (N2 assay) were ca. 3 900 GC/100 ml (Helsinki), 6600 GC/ 100 ml (Espoo), 20000 GC/100 ml (Vaasa), 35000 GC/100 ml (Jyväskylä) and $6200 \mathrm{GC} / 100 \mathrm{ml}$ (Kouvola). Concentrate volumes of $0.4 \mathrm{ml}$ (equivalent to 40 $\mathrm{ml}$ sample volume) were used for cell cultures. The samples were filtrated $(0.22 \mu \mathrm{m}$ pore size $)$ before inoculated on Vero E6 cells growing in $25 \mathrm{~cm}^{2}$ cell culture flasks for $1 \mathrm{~h}$ at $37^{\circ} \mathrm{C}$ and $5 \mathrm{ml}$ of fresh culture medium Eagle minimal essential medium (Eagle-MEM) (Sigma-Aldrich) supplemented with $2 \%$ fetal bovine serum (Sigma-Aldrich) was added for incubation. The cytopathic effect was observed under a light microscope daily during the six days of culture. After that, as a second passage, an aliquot of each cell culture supernatant was inoculated on fresh cells 
medRxiv preprint doi: https://doi.org/10.1101/2021.10.05.21264462; this version posted October 7, 2021. The copyright holder for this preprint (which was not certified by peer review) is the author/funder, who has granted medRxiv a license to display the preprint in It is made available under a CC-BY-NC-ND 4.0 International license .

the same way as described earlier. A volume of $100 \mu \mathrm{l}$ of the supernatant samples was collected daily for RNA extraction.

In addition, one WW sample was collected on 12 April 2021 during the peak of the epidemic from Helsinki WWTP and was used fresh to test the virus infectivity in the Vero E6 cell culture. A $500 \mathrm{ml} \mathrm{WW} \mathrm{sample} \mathrm{was} \mathrm{concentrated} \mathrm{with} \mathrm{dextran-} \mathrm{polyethylene} \mathrm{glycol} \mathrm{(PEG)-mixture} \mathrm{following}$ the standard procedure described in the Polio Laboratory Manual (Hovi et al., 2001). Both the original and concentrated samples were further filtrated using $0.22 \mu \mathrm{m}$ pore size membrane filters and incubated with penicillin-streptomycin-gentamycin antibiotics for $15 \mathrm{~min}$ at room temperature . Aliquots of both samples $(100 \mu \mathrm{l}$ of the concentrate equivalent to $3.3 \mathrm{ml}$ of the original WW sample) were diluted in 1:1 with the culture medium supplemented with $2 \%$ fetal bovine serum (Sigma-Aldrich) and inoculated in five replicates on the Vero E6 cells growing in $2 \mathrm{~cm}^{2}$ cell culture wells (24-well plate) for $1 \mathrm{~h}$ at $37^{\circ} \mathrm{C}$ after which $500 \mu \mathrm{l}$ of fresh media was added on the cells. The cytopathic effect was observed under a light microscope daily during the three days of culture. After the third day, as a second passage, an aliquot of each cell culture supernatant was inoculated on fresh cells the same way as described earlier. A Finnish SARS-CoV-2 isolate hCoV19/Finland/3/2020 (Gisaid number EPI_ISL_2365908) was used as a positive control. A volume of $100 \mu \mathrm{l}$ aliquot of the supernatant samples was collected for RNA extraction on Day 0 and Day 3 from both passages.

The detection of SARS-CoV-2 RNA in the cell culture aliquots was done as described earlier (Jiang et al. 2021). Briefly, the RNA extraction was done with RNEasy mini kit (Qiagen), and detection of SARS-CoV-2 was done by using RT-qPCR assay targeting the E gene (Corman et al., 2020). 
medRxiv preprint doi: https://doi.org/10.1101/2021.10.05.21264462; this version posted October 7, 2021. The copyright holder for this preprint (which was not certified by peer review) is the author/funder, who has granted medRxiv a license to display the preprint in It is made available under a CC-BY-NC-ND 4.0 International license .

\subsection{Data analysis and reporting of the SARS-CoV-2 results}

Throughout the WW-based SARS-CoV-2 RNA monitoring efforts, the outcomes of the wastewater analysis were shared with governmental and local health authorities in Finland. The WW-based SARS-CoV-2 results were manually compared to reported new COVID-19 cases within the WWTP sewer network area municipalities. In case of any discrepancies between the clinical (individual testing) and environmental (wastewater testing) surveillance, direct contact by phone or email was made by THL's personnel to the communicable disease doctor in charge of the corresponding hospital district. SARS-CoV-2 copy numbers of N2 assay were normalized with the influent flow at the sampled WWTP over each 24-h composite sampling event. Further, the numbers of inhabitants in the WWTP area were taken into consideration in presenting the SARS-CoV-2 RNA copy numbers, published weekly on THL's website:

(https://www.thl.fi/episeuranta/jatevesi/jatevesiseuranta_viikkoraportti.html).

To compare flowrate- and crAssphage-based normalization methods for N2 assay copy numbers, normalized copy numbers were calculated by dividing the $\mathrm{N} 2$ copy number per $100 \mathrm{ml}$ by the crAssphage copy number per $100 \mathrm{ml}$ of wastewater from all WWTP's samples during the period from 1 November 2020 to 31 May 2021.

\subsection{Statistical analysis}

Statistical analysis was conducted using IBM SPSS statistics 27 and R (R Core Team, 2019). Figure illustrations were made using OriginPro (2017). Statistical tests were considered statistically significant when the p-value was $<0.05$. For comparing SARS-CoV-2 RNA in WW influent to the 14-day COVID-19 case incidence rate, the 693 samples in total were converted into categorical interval data as follows: (a) at first, all the data tables were re-arranged based on ascending order of COVID-19 incidence, (b) then all samples with zero incidence cases were grouped into one category, (c) then categorical groups with 20 incidence case from lower to higher were categorized per group, and (d) out of 20 samples, the detection percentage of SARS-CoV-2 RNA per each 
medRxiv preprint doi: https://doi.org/10.1101/2021.10.05.21264462; this version posted October 7, 2021. The copyright holder for this preprint (which was not certified by peer review) is the author/funder, who has granted medRxiv a license to display the preprint in It is made available under a CC-BY-NC-ND 4.0 International license .

interval was calculated; uncertain results were grouped into a detected category. For calculating the 14-day COVID-19 case incidence rate threshold values for detecting and quantifying SARS-CoV-2 RNA with N2 assay in WW influent, binary logistic regression analysis was used employing Hosmer-Lemeshow goodness of fit, where classification cutoff was 0.5 and maximum iterations 20.

By using the quantitative SARS-CoV-2 results in WW, linear regression analysis with multiple explaining variables for 14-day COVID-19 case incidence rate was conducted. In the preliminary data analysis for determining the most significant factor, COVID-19 incidence in the sewer network area, the number of customers per WWTP, wastewater influent inflow volume, sample collection month, and the sample temperature after transport all had a strong positive correlation (data not shown). Therefore, by avoiding the multicollinearity effect, we included only flow-corrected SARS-CoV-2 GC/day/100 000 persons, the temperature of the sample at arrival in the laboratory, and the number of days delay during sample transportation as explaining variables in the multiple linear regression analysis. In models for individual WWTPs, groups of large and small WWTPs, and all samples from 28 WWTPs pooled together, 14-day COVID-19 case incidence rate was used as the dependent variable. To include uncertain and detected results below LOQ to models, $25 \%$ of LOQ copy numbers for uncertain results and $50 \%$ for detected results were given and then normalized as described above. Flow-corrected copy numbers were replaced to linear models described above with copy numbers normalized against the sample crAssphage content to test crAssphage GC as a normalization method.

The Kruskal-Wallis test was used for determining the effect of population size of sewer network areas on SARS-CoV-2 detection in WW and 14-day COVID-19 case incidence rate, and sample transportation delays on the SARS-CoV-2 detection frequency in the influent wastewaters of WWTPs. The detection frequency between N2 and E-Sarbeco assays was compared with crosstabulation followed by a Chi-square test by pooling samples from all WWTPs. 
medRxiv preprint doi: https://doi.org/10.1101/2021.10.05.21264462; this version posted October 7, 2021. The copyright holder for this preprint (which was not certified by peer review) is the author/funder, who has granted medRxiv a license to display the preprint in It is made available under a CC-BY-NC-ND 4.0 International license .

\section{Results}

\subsection{National detection and quantification thresholds}

The relationship between the 14-day COVID-19 case incidence rate and the WW-based SARSCoV-2 detection and quantification rates was examined at the national level in Finland. COVID-19 incidence in the sewer network areas gradually increased the SARS-CoV-2 detection rate until reaching 100\% in WW influent samples (Table 2, Figure 2). Based on the logistic regression analysis, the 14-day COVID-19 incidence was 7, 18 and 36 cases within the sewer network area when the probability to detect SARS-CoV-2 RNA in wastewater samples was $50 \%, 75 \%$ and $95 \%$, respectively (Figure 3).

The quantification rate of SARS-CoV-2 RNA increased almost constantly as the COVID-19 incidence increased in the sewer network area but did not reach $100 \%$ during the study period (Table 2, Figure 2). In fact, as compared to the SARS-CoV-2 GC detection rate in WW, the quantification of SARS-CoV-2 required significantly more COVID-19 cases: the quantification rate was 50\%, 75\% and 95\% when the 14-day incidence was 110, 152 and 223 COVID-19 cases, respectively, per 100000 persons (Figure 3).

During the 10 months of the study period, a national view with WW data originating from 28 WWTPs is provided with ascending and descending phases of the COVID-19 incidence in the country. However, the incidence trend variations between the first three months (ascending phase), the middle four months (plateau phase) and the last three months (descending phase) displayed only minor changes in the WW-based detection and quantification rates (Figure 2).

During the study period, the COVID-19 incidence trend gradually increased from August 2020 when the mean $( \pm$ SE) 14-DMS per 100000 population was $4.5 \pm 0.7$, until December when the 14-

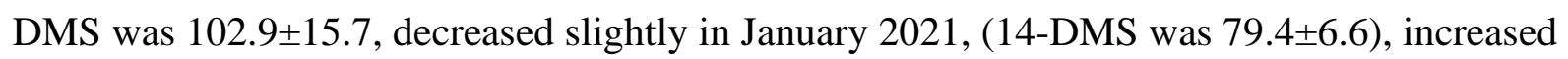

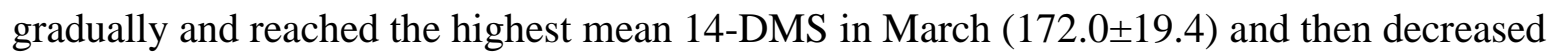


medRxiv preprint doi: https://doi.org/10.1101/2021.10.05.21264462; this version posted October 7, 2021. The copyright holder for this preprint (which was not certified by peer review) is the author/funder, who has granted medRxiv a license to display the preprint in It is made available under a CC-BY-NC-ND 4.0 International license .

gradually by the end of the study period, May 2021, when 14-DMS was 63.2 \pm 8.0 per 100000 population (Figure 1). Consistent with COVID-19 trends, the SARS-CoV-2 detection rate varied, being $38 \%$ in August and $91 \%$ in December, reaching its peak at $95 \%$ in February, and dropping to 90\% in March and 71\% in May. Similarly, the WW influent flowrate-normalized SARS-CoV-2 RNA copy number (mean \pm SE) changed according to COVID-19 incidence trends: $7.00 \pm 0.01$ in August and $7.15 \pm 0.15$ in September, reaching its peak at $7.58 \pm 0.07$ in March and decreasing to the value of $7.36 \pm 0.10 \mathrm{GC} /$ person/day in May.

\subsection{COVID-19 incidence determines the SARS-CoV-2 detection and quantification in wastewater at each WWTP}

SARS-CoV-2 RNA was detected in 79\% (including 6\% uncertain) out of a total of 693 samples analyzed with N2 assay (Table 3). Among them, only $24 \%$ of the total samples had a GC above the LOQ, with a clear difference in the quantification rates between the large (33\%) and small (12\%) WWTPs.

The SARS-CoV-2 RNA detection rate varied in WWTPs located in different cities following the COVID-19 incidence (Table 3). The highest detection rates (95\% or higher) of SARS-CoV-2 in WW were recorded in Helsinki, Espoo, and Turku, where the mean COVID-19 incidence rates per 100000 persons exceeded 100, but also in Jyväskylä and Hämeenlinna, where the mean COVID-19 incidence was around 60. In all these locations, SARS-CoV-2 was quantifiable in at least $35 \%$ of the WW samples analyzed. However, cities with a small population, namely Vihti and Salo, exhibited the highest mean SARS-CoV-2 RNA GC counts in WW: $7.72 \pm 0.23$ and $7.89 \pm 0.40 \log _{10}$ GC/day/person, respectively. At the other extreme, the WW-based SARS-CoV-2 GC never exceeded the LOQ and the median values of COVID-19 incidence were always less than 30 per 100 000 persons (14-DMS) in WWTPs of Pori, Joensuu, Rovaniemi, Seinäjoki, and Kemi, where the SARS-CoV-2 detection rates in WW were 57\%, 76\%, 71\%, 57\%, and 33\%, respectively. At 13 WWTPs where the median of 14-day COVID-19 case incidence rate was 8.9-66.5 per 100000 
medRxiv preprint doi: https://doi.org/10.1101/2021.10.05.21264462; this version posted October 7, 2021. The copyright holder for this preprint (which was not certified by peer review) is the author/funder, who has granted medRxiv a license to display the preprint in It is made available under a CC-BY-NC-ND 4.0 International license .

population, the SARS-CoV-2 RNA detection rate in WW was quite high, up to 95\%, while the quantification rate remained less than $20 \%$.

Linear regression was conducted to determine whether the number of customers or WW influent inflow volumes of WWTP, sample temperature after transport to the laboratory, sample collection month, or delay in sample processing can affect the relationship between the WW SARS-CoV-2 GC and the COVID-19 incidence. Of these, three factors; SARS-CoV-2 GC, sample temperature upon arrival at the laboratory, and sample processing delay collectively accounted for a $36 \%$ variation in overall COVID-19 incidence (Table 3). Sample temperature upon arrival at laboratory and transportation delay affected the $p$-value of the linear regression but SARS-CoV-2 GC was the only significant factor determining COVID-19 incidence alone.

The regression model indicated a significant relationship between the WW-based SARS-CoV-2 GC and the COVID-19 incidence in total at 15 out of 28 WWTPs (Table 3). At four out of the thirteen WWTPs where a significant relationship was not found, the GC of SARS-CoV-2 RNA remained below the quantification limit during the whole study period. In the other five WWTPs, the sewer coverage was less than $80 \%$ of the total population in the area and thus the COVID-19 cases may have been inhabitants from the areas not covered. In general, larger cities had higher mean COVID-19 incidence rates, and SARS-CoV-2 detection and quantification rates and mean copy numbers in wastewater $(p<0.001)$ and thus the linear regression were in better agreement in the group of large cities than small cities (Table 3). 
medRxiv preprint doi: https://doi.org/10.1101/2021.10.05.21264462; this version posted October 7, 2021. The copyright holder for this preprint (which was not certified by peer review) is the author/funder, who has granted medRxiv a license to display the preprint in It is made available under a CC-BY-NC-ND 4.0 International license .

Trends in reported new COVID-19 cases varied in the sewer network areas of the 28 WWTPs (Figures 4A-4G). The national capital region (Helsinki and Espoo) and the thirdlargest city and maritime gateway from Sweden, Turku, were constantly the major hotspots for COVID-19. These hotspots and other neighboring cities (Hämeenlinna, Lahti, and Vihti) had two major waves of COVID-19 during the surveillance period; the first wave in November-December 2020 and the main wave in March-April 2021 (Figure 4A and 4B). In other locations, namely the cities of Salo, Rauma, Maarianhamina, Kokkola, Savonlinna and Lappeenranta, there was a one-time COVID-19 peak in March-April 2021 (Figure 4C-4F). The north-western coastal cities of Vaasa, Pietarsaari, Rovaniemi, and Kemi had a one-time peak in October-November 2020 (Figure 4C, 4E, and 4G).

\subsection{SARS-CoV-2 viability and methodological aspects in wastewater}

The cell culturing attempts for the selected WW samples indicated that the SARS-CoV-2 target was non-viable in the samples analyzed.

Further, the WW-based SARS-CoV-2 RNA assay target was found to significantly affect the surveillance outcomes. Out of the total of 386 samples analyzed using both N2 and ESarbeco assays, the detection rate with N2 assay was significantly higher than with E-Sarbeco assay $\left[X^{2}(1)>=183.4, p<0.0001\right]$. All except four samples that were positive for SARSCoV-2 with E-Sarbeco assay were also positive with N2 assay. Notably, $14 \%$ of samples proven to contain SARS-CoV-2 with N2 assay were assigned as false-negative with ESarbeco assay. Even though Spearman's correlation coefficient $(\rho)$ between the detection of SARS-CoV-2 RNA with N2-assay and E-Sarbeco assays was $0.676(p<0.0001)$, SARSCoV-2 RNA was consistently more frequently detected with N2-assay than with E-Sarbeco assay throughout all sampling months. Due to the lower sensitivity of the E-Sarbeco assay, it was no longer used after January 2021 for the national WW-based surveillance. 
medRxiv preprint doi: https://doi.org/10.1101/2021.10.05.21264462; this version posted October 7, 2021. The copyright holder for this preprint (which was not certified by peer review) is the author/funder, who has granted medRxiv a license to display the preprint in It is made available under a CC-BY-NC-ND 4.0 International license .

The multiple linear regression analysis conducted indicated that crAssphage is an insufficient normalization method for WBE since a significant relationship between 14-day COVID-19 case incidence rate and crAssphage corrected SARS-CoV-2 GC numbers in WW was found only for two out 28 WWTPs. The corresponding relationship when using flowcorrected SARS-CoV-2 numbers was found in total at 15 out of 28 WWTPs (Table 3). However, crAssphage assay seemed to provide useful results in the ultrafiltration method performance testing, where this DNA-based assay resulted in higher recovery rates Ultrafiltration recovery efficiencies (68.9-110.3\%) as compared to the mengovirus, a nonenveloped RNA-virus, recovery (0-76.9\%).

\section{Discussion}

This study reports the surveillance results of SARS-CoV-2 RNA analyzed from 28 WWTPs in Finland between August 2020 to May 2021. By using cell culture-based viability assays for selected samples, the study also provides further evidence that SARS-COV-2 coronaviruses do not pose a waterborne transmission risk as they remain non-viable in community wastewater influents as stated by others (Rimoldi et al. 2020, Westhaus et al. 2021, Ahmed et al. 2021c).

By analyzing a total of $693 \mathrm{WW}$ samples, we found that WW-based detection of SARSCoV-2 from multiple locations is an effective measure for tracing national trends in COVID19. By using the ultrafiltration method and N2 RT-qPCR assay, the relative quantification of SARS-CoV-2 numbers was possible at 50\% probability, when the COVID-19 incidence rate in the sewer network area exceeded 152 cases per 100000 persons. The SARS-CoV-2 detection reached 50\% probability already when the preceding 14-day COVID-19 case incidence rate was about seven cases per 100000. 
medRxiv preprint doi: https://doi.org/10.1101/2021.10.05.21264462; this version posted October 7, 2021. The copyright holder for this preprint (which was not certified by peer review) is the author/funder, who has granted medRxiv a license to display the preprint in It is made available under a CC-BY-NC-ND 4.0 International license .

The COVID-19 trend was highly variable between the sewer network areas throughout the country, with the large cities (Helsinki, Espoo, and Turku) having the most influence on the national trends of COVID-19 incidence. These large cities were consistently the nation's pandemic hotspots, which is not surprising as these cities are the major financial, tourist, and education hubs and gateways to the country from abroad. Overall, the detection trend of SARS-CoV-2 RNA in WW had a strong relationship with reported new COVID-19 cases in the sewer network area and showed good agreement with earlier studies (Wang et al. 2020, Gonzalez et al. 2020, Westhaus et al. 2021). The monitoring of SARS-CoV-2 RNA in WW captured both trends and peaks of COVID-19 incidences, both at local and national levels. The WW-based SARS-CoV-2 surveillance data often followed the same sequence: SARSCoV-2 was first detected as an uncertain observation, then detected but below LOQ quantities, and finally quantified after a further increase in COVID-19 incidence, illustrating the simultaneous spread of COVID-19 cases in individual testing among the inhabitants of the studied sewer network areas.

Although traces of SARS-CoV-2 in WW might remain below the limit of detection (LOD) or at least below the limit of quantification (LOQ) of the method (Ahmed et al. 2020, Ahmed et al. 2021b), the data presented herein demonstrates a clear connection between the change in COVID-19 incidence noted in the individual testing and the presence and quantity of SARS-CoV-2 RNA in WW. In communities where COVID-19 infection rates are low, RNA is less likely to be quantified in WW and the reporting systems need to function with the available binary results (SARS-CoV-2 detected/non-detected). In our study, the sole reliance on the quantified SARS-CoV-2 GC WW results would have caused a loss of most of our results $(\sim 76 \%)$. In the WWTPs of five cities (Pori, Joensuu, Rovaniemi, Seinäjoki, and Kemi, where 14-day COVID-19 case incidence rate was always less than 27), SARS-CoV-2 RNA was not quantified in any of the studied WW samples. Indeed, some earlier studies have also 
medRxiv preprint doi: https://doi.org/10.1101/2021.10.05.21264462; this version posted October 7, 2021. The copyright holder for this preprint (which was not certified by peer review) is the author/funder, who has granted medRxiv a license to display the preprint in It is made available under a CC-BY-NC-ND 4.0 International license .

reported a poor correlation between COVID-19 incidence with SARS-COV-2 RNA copies mainly during periods of low COVID-19 incidence (Hillary et al. 2020, Ahmed et al. 2021a).

In our study, only six out of 693 WW samples were positive with SARS-COV-2 RNA when the reported 14-day COVID-19 case incidence was zero. While the detection of SARSCoV-2 RNA in WW influent infers there being at least one person with COVID-19 shedding SARS-CoV-2 into the WW in the sewer network area, the NIDR collects the individual test positivity results based on the municipality of residence. However, due to the pandemic and the recommendation not to travel, the movement of people between municipalities could have been during the study period lower than usual. Further, although individual COVID-19 tests were available for all symptomatic people in Finland over the study duration, not everyone is willing to be tested and the infected person can also be asymptomatic, pre-symptomatic, or post-symptomatic.

Conversely, the non-detection of SARS-CoV-2 RNA in WW influents does not guarantee the absence of infected people in the sewer network area. The possible reasons for nondetection in WW can be due to (a) an absence of infected people, (b) the virus load is below the WW method LOD, or (c) the periodic flow of the virus with limited numbers of infected people has not been captured during the period of sample collection. Further, the mixing with other WW flows, stormwater infiltration, the diurnal variation in shedding, and hydraulic residence time in the sewer collection system, can also affect the probability of detection of SARS-CoV-2 RNA, particularly in low prevalence conditions (Ahmed et al. 2020, Hillary et al. 2021). The higher sensitivity of N2 assay than E-Sarbeco assay in our hands and some contradictory results reported earlier in relation to $\mathrm{N} 2$ assay performance (Ahmed et al. 2021a; Gerrity et al. 2021) highlights the need for special attention during the selection of RTqPCR assay for SARS-CoV-2 determinations from WW. 
medRxiv preprint doi: https://doi.org/10.1101/2021.10.05.21264462; this version posted October 7, 2021. The copyright holder for this preprint (which was not certified by peer review) is the author/funder, who has granted medRxiv a license to display the preprint in It is made available under a CC-BY-NC-ND 4.0 International license .

\section{Conclusions}

- This study shows a clear relationship between the 14-day COVID-19 case incidence rate in sewer network areas and the detection and quantification rate of SARS-CoV-2 RNA in WW influent samples of respective WWTPs.

- The 14-day COVID-19 case incidence of 7.0 per 100000 persons yielded about $50 \%$ probability of detecting SARS-CoV-2 from wastewater samples, and a 95\% wastewater detection rate was reached when the COVID-19 incidence was about 36 cases per 100000 persons.

- A much higher 14-day COVID-19 case incidence rate was required to quantify than to detect SARS-CoV-2 from the wastewater samples. $50 \%$ and $95 \%$ probability to quantify SARS-CoV-2 in wastewater was achieved when the 14-day COVID-19 case incidence was 110 and 223 per 100000 persons, respectively.

- This finding supports the use of binary (detected/not-detected) results of SARS-CoV-2 RNA monitoring as a basis of WW-based surveillance results reporting during periods of low COVID-19 incidence.

- This study did not find viable SARS-CoV-2 particles in WW samples. 
medRxiv preprint doi: https://doi.org/10.1101/2021.10.05.21264462; this version posted October 7, 2021. The copyright holder for this preprint (which was not certified by peer review) is the author/funder, who has granted medRxiv a license to display the preprint in It is made available under a CC-BY-NC-ND 4.0 International license .

\section{Author contributions}

AT, AL and AH have contributed equally on the work. AT wrote the first draft of the manuscript; AL conducted the initial RT-qPCR result calculation and data interpretation; and $\mathrm{AH}$ was in charge of the wastewater collection and analysis. AL, AH, AS, and AR undertook the wastewater investigations, processing, and analysis of the laboratory data. AL, AH, OL, and AJ undertook the processing and analysis of the epidemiological data. PO and HA were in charge of the cell culture work in SARS-CoV-2 viability assessments. IM and CSK provided resources for the team. AT, AL, OL, and TP led the data interpretation and the writing of the manuscript. TP and CSK conceptualized the project, supervised the work, and oversaw funding acquisition. TP prepared and all authors contributed to the final draft of the article.

\section{Declaration of Competing Interest}

The authors declare that they have no known competing financial interests or personal relationships that could have appeared to influence the work reported in this paper.

\section{Acknowledgements}

The authors would like to express special thanks to Marjo Tiittanen, Mirka Korhonen, Mari Turunen, Tarja Rahkonen, Tiina Heiskanen, Eveliina Nurmi, Kristiina Valkama and Arja Moilanen for their assistance in the laboratory, and Aino Kankaanpää for her help with sample transportation arrangements. The personnel of the wastewater treatment facilities in all 28 wastewater-based SARS-CoV-2 surveillance locations in Finland are highly acknowledged for their support and timely efforts for wastewater composite sampling and sample transportation arrangements for the work. Further, we acknowledge the NORMAN Network, COVID-19 WBE Collaborative, and European Commission Initiative "SARS-CoV-2 monitoring employing sewers" for sharing their knowledge and resources for this work. 
medRxiv preprint doi: https://doi.org/10.1101/2021.10.05.21264462; this version posted October 7, 2021. The copyright holder for this preprint (which was not certified by peer review) is the author/funder, who has granted medRxiv a license to display the preprint in It is made available under a CC-BY-NC-ND 4.0 International license .

\section{References}

Ahmed W, Angel N, Edson J, Bibby K, Bivins A, O'Brien JW, Choi PM, Kitajima M, Simpson SL, Li J, Tscharke B, Verhagen R, Smith WJM, Zaugg J, Dierens L, Hugenholtz P, Thomas KV, Mueller JF (2020). First confirmed detection of SARS-CoV-2 in untreated wastewater in Australia: A proof of concept for the wastewater surveillance of COVID-19 in the community. Sci Total Environ. 138764. Doi:10.1016/J.SCITOTENV.2020.138764.

Ahmed W, Tscharke B, Bertsch PM, Bibby K, Bivins A, Choi P, Clarke L, Dwyer J, Edson J, Nguyen TMH, O'brien JW, Simpson SL, Sherman P, Thomas KV, Verhagen R, Zaugg J, Mueller JF (2021a). SARS-CoV-2 RNA monitoring in wastewater as a potential early warning system for COVID-19 transmission in the community: A temporal case study. Sci Total Environ. 761:144216. Doi:10.1016/j.scitotenv.2020.144216.

Ahmed W, Simpson S, Bertsch P, Bibby K, Bivins A, Blackall L, Bofill-Mas S, Bosch A, Brandao J, Choi P, Ciesielski M, Donner E, D'Souza N, Farnleitner A, Gerrity D, Gonzalez R, Griffith J, Gyawali P, Haas C, Hamilton K, Hapuarachchi C, Harwood V, Haque R, Jackson G, Khan S, Khan W, Kitajima M, Korajkic A, La Rosa G, Layton B, Lipp E, McLellan S, McMinn B, Medema G, Metcalfe S, Meijer W, Mueller J, Murphy H, Naughton C, Noble R, Payyappat S, Petterson S, Pitkänen T, Rajal V, Reyneke B, Roman F, Rose J, Rusinol M, Sadowsky M, Sala-Comorera L, Setoh YX, Sherchan S, Sirikanchana K, Smith W, Steele J, Sabburg R, Symonds E, Thai P, Thomas K, Tynan J, Toze S, Thompson J, Whiteley A, Wong J, Sano D, Wuertz S, Xagoraraki I, Zhang Q, Zimmer-Faust A, Shanks O. (2021b). Minimizing Errors in RT-PCR Detection and Quantification of SARS-CoV-2 RNA for Wastewater Surveillance. Sci Total Environ. Doi:10.1016/j.scitotenv.2021.149877.

Ahmed W, Bibby K, D'Aoust PM, Delatolla R, Gerba CP, Haas CN, Hamilton KA, Hewitt J, Julian TR, Kaya D, Monis P, Moulin L, Naughton C, Noble RT, Shrestha A, Tiwari A, Simpson SL, Wurtzer S, Bivins A (2021c). Differentiating between the possibility and probability of SARS-CoV-2 transmission associated with wastewater: empirical evidence is needed to substantiate risk, FEMS Microbes; 2: xtab007. Doi:10.1093/femsmc/xtab007.

Cevik M, Tate M, Lloyd O, Maraolo AE, Schafers J, Ho A (2021). SARS-CoV-2, SARSCoV, and MERS-CoV viral load dynamics, duration of viral shedding, and infectiousness: a systematic review and meta-analysis. The Lancet Microbe. 2(1): E13-E22.

Doi:10.1016/S2666-5247(20)30172-5

Corman VM, Landt O, Kaiser M, Molenkamp R, Meijer A, Chu DK, Bleicker T, Brünink S, Schneider J, Schmidt ML, Mulders DG, Haagmans BL, van der Veer B, van den Brink S, Wijsman L, Goderski G, Romette JL, Ellis J, Zambon M, Peiris M, Goossens H, Reusken C, Koopmans MP, Drosten C (2020). Detection of 2019 novel coronavirus (2019-nCoV) by realtime RT-PCR. Euro Surveill. 25(3):2000045. Doi: 10.2807/15607917.ES.2020.25.3.2000045.

Gerrity D, Papp K, Stoker M, Sims A, Frehner W. (2021) Early-pandemic wastewater surveillance of SARS-CoV-2 in Southern Nevada: Methodology, occurrence, and 
medRxiv preprint doi: https://doi.org/10.1101/2021.10.05.21264462; this version posted October 7, 2021. The copyright holder for this preprint (which was not certified by peer review) is the author/funder, who has granted medRxiv a license to display the preprint in It is made available under a CC-BY-NC-ND 4.0 International license .

incidence/prevalence considerations. Water Res X. 10: 100086.

Doi:10.1016/j.wroa.2020.100086.

Gonzalez R, Curtis K, Bivins A, Bibby K, Weir MH, Yetka K, Thompson H, Keeling D, Mitchell J, Gonzalez D (2020). COVID-19 surveillance in southeastern Virginia using wastewater-based epidemiology. Water Res. 186:116296. Doi:10.1016/j.watres.2020.116296.

Gracia-Lor E, Castiglioni S, Bade R, Been F, Castrignanò E, Covaci A, González-Mariño I, Hapeshi E, Kasprzyk-Hordern B, Kinyua J, Lai FY, Letzel T, Lopardo L, Meyer MR, O'brien J, Ramin P, Rousis NI, Rydevik A, Ryu Y, Santos MM, Senta I, Thomaidis NS, Veloutsou S, Yang Z, Zuccato E, Bijlsma L (2017). Measuring biomarkers in wastewater as a new source of epidemiological information: Current state and future perspectives. Environ Int. 99:131150. Doi:10.1016/j.envint.2016.12.016.

Green H, Wilder M, Collins M, Fenty A, Gentile K, Kmush BL, Zeng T, Middleton FA, Larsen DA (2020). Quantification of SARS-CoV-2 and cross-assembly phage (crAssphage) from wastewater to monitor coronavirus transmission within communities. medRxiv 2020.05.21.20109181. Doi:10.1101/2020.05.21.20109181Y.

Hart OE, Halden RU (2020). Computational analysis of SARS-CoV-2/COVID-19 surveillance by wastewater-based epidemiology locally and globally: Feasibility, economy, opportunities and challenges. Sci Total Environ. 730:138875. Doi: 10.1016/j.scitotenv.2020.138875.

Hillary LS, Farkas K, Maher KH, Lucaci A, Thorpe J, Distaso MA, Gaze WH, Paterson S, Burke T, Connor TR, McDonald JE, Malham SK, Jones DL (2021). Monitoring SARS-CoV2 in municipal wastewater to evaluate the success of lockdown measures for controlling COVID-19 in the UK. Water Res. 117214. Doi: 10.1016/j.watres.2021.117214.

Hokajärvi AM, Rytkönen A, Tiwari A, Kauppinen A, Oikarinen S, Lehto KM, Kankaapää A, Gunnar T, Al-Hellow H, Blomqvist S, Miettinen IT, Savolainen-Kopra C, Pitkänen T. (2021). The detection and stability of the SARS-CoV-2 RNA biomarkers in wastewater influent in Helsinki, Finland. Sci Total Environ. 770:145274. Doi: 10.1016/j.scitotenv.2021.145274.

Hovi T., Stenvik M., Partanen H., Kangas A. (2001) Poliovirus surveillance by examining sewage specimens. Quantitative recovery of virus after introduction into sewerage at remote upstream location. Epidemiol Infect, 127 (1): 101-6. Doi:10.1017/s0950268801005787

ISO/TS 15216-1. 2013. Microbiology of food and animal feed - Horizontal method for determination of hepatitis A virus and norovirus in food using real-time RT-PCR -Part 1: Method for quantification. International Organization for Standardization, Geneva, Switzerland.

Jiang M, Kolehmainen P, Kakkola L, Maljanen S, Melén K, Smura T, Julkunen I, Österlund P (2021). SARS-CoV-2 isolates show impaired replication in human immune cells but differential ability to replicate and induce innate immunity in lung epithelial cells. Microbiol Spectr 9:e00774-21. Doi:10.1128/Spectrum.00774-21. 
medRxiv preprint doi: https://doi.org/10.1101/2021.10.05.21264462; this version posted October 7, 2021. The copyright holder for this preprint (which was not certified by peer review) is the author/funder, who has granted medRxiv a license to display the preprint in It is made available under a CC-BY-NC-ND 4.0 International license .

Kumar M, Patel AK, Shah AV, Raval J, Rajpara N, Joshi M, Joshi CG (2020). First proof of the capability of wastewater surveillance for COVID-19 in India through detection of genetic material of SARS-CoV-2. Sci Total Environ. 746:141326.

Doi:10.1016/j.scitotenv.2020.141326.

Li X, Zhang S, Shi J, Luby SP, Jiang G. (2021) Uncertainties in estimating SARS-CoV-2 prevalence by wastewater-based epidemiology. Chem Eng J. 415:129039.

Doi:10.1016/j.cej.2021.129039

Lorenzo M and Picó Y (2019). Wastewater-based epidemiology: Current status and future prospects. Curr Opin Environ Sci. 9:77-84. Doi:10.1016/j.coesh.2019.05.007.

Lu, X., Wang, L., Sakthivel, S.K., Whitaker, B., Murray, J., Kamili, S., Lynch, B., Malapati, L., Burke, S.A., Harcourt J., Tamin A., Thornburg, N.J., Villanueva, J.M., Lindstrom S., (2020). US CDC real-time reverse transcription PCR panel for detection of severe acute respiratory syndrome coronavirus 2. Emerg Infect Dis. 26(8), 1654-1665. doi: 10.3201/eid2608.201246.

Lundy L, Fatta-Kassinos D, Slobodnik J, Karaolia P, Cirka L, Kreuzinger N, Castiglioni S, Bijlsma L, Dulio V, Deviller G, Lai FY, Alygizakis N, Barneo M, Baz-Lomba JA, Béen F, Cíchová M, Conde-Pérez K, Covaci A, Donner E, Ficek A, Hassard F, Hedström A, Hernandez F, Janská V, Jellison K, Hofman J, Hill K, Hong PY, Kasprzyk-Hordern B, Kolarević S, Krahulec J, Lambropoulou D, de Llanos R, Mackul'ak T, Martinez-García L, Martínez F, Medema G, Micsinai A, Myrmel M, Nasser M, Niederstätter H, Nozal L, Oberacher H, Očenášková V, Ogorzaly L, Papadopoulos D, Peinado B, Pitkänen T, Poza M, Rumbo-Feal S, Sánchez MB, Székely AJ, Soltysova A, Thomaidis NS, Vallejo J, van Nuijs A, Ware V, Viklander M. (2021) Making Waves: Collaboration in the time of SARS-CoV-2 rapid development of an international co-operation and wastewater surveillance database to support public health decision-making. Water Res. 199:117167. Doi:

10.1016/j.watres.2021.117167.

Medema G, Been F, Heijnen L, Petterson S. (2020a). Implementation of environmental surveillance for SARS-CoV-2 virus to support public health decisions: Opportunities and challenges. Curr Opin Environ Sci. 17:49. Doi:10.1016/j.coesh.2020.09.006.

Medema G, Heijnen L, Elsinga G, Italiaander R, Brouwer A (2020b). Presence of SARScoronavirus-2 RNA in sewage and correlation with reported COVID-19 prevalence in the early stage of the epidemic in The Netherlands. Environ. Sci. Technol. Lett., 7 (7): 511-516. Doi:10.1021/acs.estlett.0c00357.s001.

Pintó, Rosa M., M. Costafreda, I., Bosch, A. 2009. Risk assessment in shellfish-borne outbreaks of hepatitis A. Appl. Environ. Microbiol. 75(23), doi:10.1128/AEM.01177-09.

R Core Team (2019). R: A language and environment for statistical computing. R Foundation for Statistical Computing, Vienna, Austria. URL https://www.R-project.org/.

Rimoldi SG, Stefani F, Gigantiello A, Polesello S, Comandatore F, Mileto D, Maresca M, Longobardi C, Mancon A, Romeri F, Pagani C, Cappelli F, Roscioli C, Moja L, Gismando 
medRxiv preprint doi: https://doi.org/10.1101/2021.10.05.21264462; this version posted October 7, 2021. The copyright holder for this preprint (which was not certified by peer review) is the author/funder, who has granted medRxiv a license to display the preprint in It is made available under a CC-BY-NC-ND 4.0 International license .

MR, Salerno F (2020). Presence and infectivity of SARS-CoV-2 virus in wastewaters and rivers. Sci Total Environ. 744:140911. Doi:10.1016/j.scitotenv.2020.140911

Rusiñol M, Zammit I, Itarte M, Fores E, Martinez-Puchol S, Girones R, Borrego C, Corominas L, Bofill-Mas S (2021). Monitoring waves of the COVID-19 pandemic: Inferences from WWTPs of different sizes. Sci Total Environ. 787:147463.

Doi:10.1016/j.scitotenv.2021.147463.

Sherchan SP, Shahin S, Ward LM, Tandukar S, Aw TG, Schimitz B, Ahmed W, Kitajima M. (2020). First detection of SARS-CoV-2 RNA in wastewater in North America: A study in Louisiana, USA. Sci Total Environ. 743:140621. Doi:10.1016/j.scitotenv.2020.140621.

Sims N, Kasprzyk-Hordern B. (2020). Future perspectives of wastewater-based epidemiology: Monitoring infectious disease spread and resistance to the community level. Environ Int. 139:105689. Doi:10.1016/j.envint.2020.105689

Stachler E, Kelty C, Sivaganesan M, Li X, Bibby K, Shanks OC (2017). Quantitative CrAssphage PCR Assays for Human Fecal Pollution Measurement. Environ Sci Technol. 51(16):9146-9154. Doi: 10.1021/acs.est.7b02703.

Wang W, Xu Y, Gao R, Lu R, Han K, Wu G, Tan W (2020). Detection of SARS-CoV-2 in Different Types of Clinical Specimens. JAMA. 323(18):1843-1844.

Doi:10.1001/jama.2020.3786

Weidhaas J, Aanderud ZT, Roper DK, VanDerslice J, Gaddis EB, Ostermiller J, Hoffman K, Jamal R, Heck P, Zhang Y, Torgersen K, Laan JV, LaCross N (2021). Correlation of SARSCoV-2 RNA in wastewater with COVID-19 disease burden in sewersheds. Sci Total Environ. 775:145790. Doi:10.1016/j.scitotenv.2021.145790.

Westhaus S, Weber F, Schiwy S, Linnemann V, Brinkmann M, Widera M, Greve C, Janke A, Hollert H, Wintgens T and Ciesek S (2021). Detection of SARS-CoV-2 in raw and treated wastewater in Germany - Suitability for COVID-19 surveillance and potential transmission risks. Sci Total Environ. 751(10):141750. Doi:10.1016/j.scitotenv.2020.141750.

WHO (2020). World Health Organization. Status of environmental surveillance for SARSCoV-2 virus. Available from: https://www.who.int/news-room/commentaries/detail/status-ofenvironmental-surveillance-for-sars-cov-2-virus. Accessed at 1.10.2021.

Wölfel R., Corman VM, Guggemos W, Seilmaier M, Zange S, Müller MA, Niemeyer D, Jones TC, Vollmar P, Rothe C, Hoelscher M, Bleicker T, Brünink S, Schneider J, Ehmann R, Zwirglmaier K, Drosten C, Wendtner C (2020). Virological assessment of hospitalized patients with COVID-2019. Nature. 581, 465-469. Doi:10.1038/s41586-020-2196-x.

Wu F, Xiao A, Zhang J, Moniz K, Endo N, Armas F, Bonneau R, Brown MA, Bushman M, Chai PR, Duvallet C, Erickson TB, Foppe K, Ghaeli N, Gu X, Hanage WP, Huang KH, Lee WL, Matus M, McElroy KA, Nagler J, Rhode SF, Santillana M, Tucker JA, Wuertz S, Zhao S, Thompson J, Alm EJ (2020a). SARS-CoV-2 titers in wastewater foreshadow dynamics and 
medRxiv preprint doi: https://doi.org/10.1101/2021.10.05.21264462; this version posted October 7, 2021. The copyright holder for this preprint (which was not certified by peer review) is the author/funder, who has granted medRxiv a license to display the preprint in It is made available under a CC-BY-NC-ND 4.0 International license .

clinical presentation of new COVID-19 cases. mSystems. 5(4): PMID: 32607521.

Doi:10.1101/2020.06.15.20117747.

Wu F, Xiao A, Zhang J, Moniz K, Endo N, Armas F, Bushman M, Chai PR, Duvallet C, Erickson TB, Foppe K, Ghaeli N, Gu X, Hanage WP, Huang KH, Lee WL, Mcelroy KA, Rhode SF, Matus M, Wuertz S, Thompson J, Alm EJ (2021). Wastewater surveillance of SARS-CoV-2 across 40 U.S. states from February to June 2020. Water Res. 117400. Doi: 10.1016/j.watres.2021.117400.

Wu Y, Guo C, Tang L, Hong Z, Zhou J, Dong X, Yin H, Xiao Q, Tang Y, Qu X, Kuang L, Fang X, Mishra N, Lu J, Shan H, Jiang G, Huang X (2020b). Prolonged presence of SARSCoV-2 viral RNA in faecal samples. Lancet Gastroenterol Hepatol. 5(5): 434-435.

Doi:10.1016/S2468-1253(20)30083-2. 
Table 1. Wastewater influent samples collected at the 28 WWTPs between 3 August 2020 and 31 May 2021, Finland.

\begin{tabular}{|c|c|c|c|c|c|c|c|c|c|}
\hline \multirow[t]{2}{*}{ WWTP, location } & \multirow[t]{2}{*}{$\mathbf{N}$} & \multicolumn{2}{|c|}{ 24h-composite sampling } & \multirow{2}{*}{$\begin{array}{c}\text { Industrial } \\
\text { WW } \\
\text { Proportion, } \\
\%\end{array}$} & \multirow{2}{*}{$\begin{array}{c}\text { 24-h WW } \\
\text { influent volume } \\
\text { Mean } \pm \text { SE, * }\end{array}$} & \multicolumn{2}{|c|}{$\begin{array}{c}\text { Temperature, } \\
\text { Median (Min-Max) }\end{array}$} & \multirow{2}{*}{$\begin{array}{l}\text { Transit time (days) } \\
\text { Median (Min-Max) }\end{array}$} & \multirow{2}{*}{$\begin{array}{c}\text { TSS (mg/l) } \\
\text { Mean (Min-Max), N }\end{array}$} \\
\hline & & Method & Interval & & & $\begin{array}{c}\text { At WWTP, } \\
{ }^{\circ} \mathrm{C}\end{array}$ & $\begin{array}{c}\text { After transit, } \\
{ }^{\circ} \mathbf{C}\end{array}$ & & \\
\hline $\begin{array}{l}\text { Viikinmäki, } \\
\text { Helsinki }\end{array}$ & 42 & Flow/time & $\begin{array}{l}3 \mathrm{x} / 10000 \mathrm{~m}^{3} / \\
20 \mathrm{~min}\end{array}$ & 7 & $34160 \pm 1000$ & $13.7(9.7-18.5)$ & $10.8(7.4-18.3)$ & $1(1-2)$ & $298.6(128-738), 42$ \\
\hline Suomenoja, Espoo & 22 & Flow & $750 \mathrm{~m}^{3}$ & 5 & $27760 \pm 1190$ & $13.4(8.5-18.1)$ & $8.9(5.7-14.5)$ & $1(1-2)$ & 295.5 (220-416), 22 \\
\hline $\begin{array}{c}\text { Kakolanmäki, } \\
\text { Turku }\end{array}$ & 42 & Flow & $\begin{array}{l}990(700- \\
1500) \mathrm{m}^{3}\end{array}$ & 15 & $26780 \pm 1530$ & $12.1(8.4-20.1)$ & $10.7(6.3-21.4)$ & $1(1-2)$ & $293.6(176-448), 20$ \\
\hline $\begin{array}{c}\text { Taskila, } \\
\text { Oulu }\end{array}$ & 41 & Time & $38 \mathrm{~min}$ & NA & $25880 \pm 770$ & $9.1(6.7-15.7)$ & $10.4(5.6-22.0)$ & $1(1-5)$ & 457.9 (230-690), 19 \\
\hline $\begin{array}{c}\text { Viinikanlahti, } \\
\text { Tampere }\end{array}$ & 41 & Flow & NA & NA & $33320 \pm 850$ & $16.2(11.6-23.5)$ & $10.2(3.7-20.9)$ & $1(1-6)$ & $437.8(220-970), 41$ \\
\hline $\begin{array}{l}\text { Nenäinniemi, } \\
\text { Jyväskylä }\end{array}$ & 21 & Flow & $\begin{array}{c}280(150-550) \\
\mathrm{m}^{3}\end{array}$ & 10 & $23610 \pm 1110$ & $11.5(7-18.2)$ & $11.2(6.6-18.4)$ & $1(1-2)$ & 740 (380-1080), 21 \\
\hline $\begin{array}{c}\text { Luotsinmäki, } \\
\text { Pori }\end{array}$ & 21 & Flow & $250 \mathrm{~m}^{3}$ & 10 & $26880 \pm 860$ & $10.4(7.9-17.4)$ & $11.1(6.6-20.8)$ & $2(1-2)$ & NA \\
\hline $\begin{array}{l}\text { Mussalo, } \\
\text { Kotka }\end{array}$ & 21 & Flow & NA & 13 & $30560 \pm 2080$ & $12.4(7.4-19.1)$ & $9.9(5.6-21.6)$ & $2(1-2)$ & 390 (390-390), 1 \\
\hline $\begin{array}{c}\text { Kuhasalo, } \\
\text { Joensuu }\end{array}$ & 21 & Flow & $\begin{array}{c}110(100-200) \\
\mathrm{m}^{3}\end{array}$ & 20 & $20490 \pm 920$ & $10.4(6.9-16)$ & $10.6(5.7-16.4)$ & $1(1-2)$ & 280.7 (240-400), 14 \\
\hline $\begin{array}{l}\text { Lehtoniemi, } \\
\text { Kuopio }\end{array}$ & 42 & Flow/time & $\begin{array}{c}1100 \mathrm{~m}^{3} / 60 \\
\min \end{array}$ & NA & $24540 \pm 730$ & $11.1(7.5-16.8)$ & $10.4(6.0-17.1)$ & $1(0-3)$ & $460(420-500), 2$ \\
\hline $\begin{array}{l}\text { Pått, } \\
\text { Vaasa }\end{array}$ & 22 & Flow & $2000 \mathrm{~m}^{3}$ & NA & $27260 \pm 1450$ & $11.6(7.6-18.4)$ & $9.0(6.0-16.7)$ & $1.5(1-2)$ & NA \\
\hline $\begin{array}{c}\text { Mäkikylä, } \\
\text { Kouvola }\end{array}$ & 22 & Flow & NA & 4.4 & $37280 \pm 2940$ & $10(5.9-15.3)$ & $9.6(4.0-20.6)$ & $1(1-3)$ & $304.7(206-520), 12$ \\
\hline $\begin{array}{c}\text { Paroinen, } \\
\text { Hämeenlinna }\end{array}$ & 21 & Flow & $\begin{array}{c}540(500-800) \\
\mathrm{m}^{3}\end{array}$ & NA & $25470 \pm 1170$ & $9.5(6.3-15.5)$ & $11.0(7.0-19.0)$ & $1(1-2)$ & NA \\
\hline $\begin{array}{c}\text { Kariniemi, } \\
\text { Lahti (I) }\end{array}$ & 21 & Flow & $180 \mathrm{~m}^{3}$ & 15 & $27670 \pm 1320$ & $13.5(8-17.7)$ & $10.4(6.4-18.7)$ & $1(1-2)$ & $289.2(150-470), 12$ \\
\hline $\begin{array}{c}\text { Toikansuo, } \\
\text { Lappeenranta }\end{array}$ & 21 & Time & $10 \min$ & 10 & $24290 \pm 1100$ & $10(4-16.2)$ & $9.4(7.0-19.3)$ & $1(1-3)$ & 454.7 (200-1400), 21 \\
\hline $\begin{array}{l}\text { Ali-Juhakkala, } \\
\text { Lahti (II) }\end{array}$ & 21 & Flow & $150 \mathrm{~m}^{3}$ & 12 & $23210 \pm 1230$ & $13.1(7.7-17.4)$ & $10.8(6.0-18.7)$ & $1(1-2)$ & 430 (220-740), 14 \\
\hline
\end{tabular}




\begin{tabular}{|c|c|c|c|c|c|c|c|c|c|}
\hline $\begin{array}{c}\text { Alakorkalo, } \\
\text { Rovaniemi }\end{array}$ & 21 & Flow & $1 \mathrm{~m}^{3}$ & NA & $32150 \pm 1260$ & $9.1(6.8-14.4)$ & $11.7(6.4-21.1)$ & $1(1-3)$ & NA \\
\hline $\begin{array}{c}\text { Keskuspuhdistamo, } \\
\text { Salo }\end{array}$ & 21 & Flow & $60 \mathrm{~m}^{3}$ & NA & $41330 \pm 13080$ & $9.2(4.8-15.3)$ & $9.7(6.5-18.9)$ & $1(1-15)$ & NA \\
\hline $\begin{array}{c}\text { Keskuspuhdistamo, } \\
\text { Seinäjoki }\end{array}$ & 21 & Flow & $400 \mathrm{~m}^{3}$ & NA & $38270 \pm 2450$ & $10(7-16)$ & $10.4(5.4-18.6)$ & $2(1-3)$ & $171.2(96-310), 5$ \\
\hline $\begin{array}{c}\text { Kenkäveronniemi, } \\
\text { Mikkeli }\end{array}$ & 21 & Flow & $50 \mathrm{~m}^{3}$ & NA & $24010 \pm 1590$ & $11.6(8.6-17.8)$ & $10.8(6.7-17.4)$ & $1(1-3)$ & $540.8(440-670), 13$ \\
\hline $\begin{array}{c}\text { Maanpäänniemi, } \\
\text { Rauma }\end{array}$ & 21 & Flow & $\begin{array}{c}340(250-500) \\
\mathrm{m}^{3} \\
\end{array}$ & 20 & $28250 \pm 1010$ & $7.5(4-15.5)$ & $10.0(5.0-17.9)$ & $1(1-2)$ & NA \\
\hline $\begin{array}{c}\text { Hopeakivenlahti, } \\
\text { Kokkola }\end{array}$ & 21 & Time & $15 \mathrm{~min}$ & 0 & $28100 \pm 1650$ & $9.3(5.5-16)$ & $9.6(5.6-20.1)$ & $2(1-2)$ & 189.7 (96-390), 13 \\
\hline $\begin{array}{c}\text { Peuraniemi, } \\
\text { Kajaani }\end{array}$ & 21 & Time & $80 \mathrm{~min}$ & 1.5 & $32050 \pm 1980$ & $10.5(4.8-16.6)$ & $13.0(7.6-20.6)$ & $2(1-2)$ & $436.7(240-670), 12$ \\
\hline $\begin{array}{l}\text { Alheda, } \\
\text { Pietarsaari }\end{array}$ & 22 & Time & $15 \mathrm{~min}$ & NA & $32390 \pm 1840$ & $8.6(6-16.3)$ & $10.0(4.7-15.0)$ & $2(1-8)$ & $320(320-320), 1$ \\
\hline $\begin{array}{c}\text { Peurasaari, } \\
\text { Kemi }\end{array}$ & 21 & Flow/time & $50 \mathrm{ml} / 10 \mathrm{~min}$ & NA & $43660 \pm 3660$ & $6.8(4.8-16.6)$ & $10.4(7.4-17.7)$ & $2(1-2)$ & $158.3(49-270) 6$ \\
\hline $\begin{array}{c}\text { Pihlajaniemi, } \\
\text { Savonlinna }\end{array}$ & 21 & Time & $\begin{array}{c}30(20-40) \\
\min \end{array}$ & NA & $33910 \pm 2170$ & $8.2(4.1-17.8)$ & $12.0(7.7-19.3)$ & $1(1-3)$ & $197.9(80-310), 21$ \\
\hline $\begin{array}{l}\text { Lotsbroverket, } \\
\text { Maarianhamina }\end{array}$ & 21 & Flow & $50 \mathrm{~m}^{3}$ & 30 & $27870 \pm 2250$ & $9.9(7-17.5)$ & $11.2(7.2-20.1)$ & $2(1-3)$ & NA \\
\hline $\begin{array}{c}\text { Nummela, } \\
\text { Vihti }\end{array}$ & 21 & Flow & $20 \mathrm{~m}^{3}$ & NA & $17600 \pm 470$ & $11.7(8-16.3)$ & $10.2(7.3-21.4)$ & $2(1-2)$ & 486 (390-580), 5 \\
\hline Total & 693 & & & $10.3(0-30)$ & $29230 \pm 540$ & $11.3(3.5-23.5)$ & $10.4(3.7-22.0)$ & $1(0-15)$ & 373.8 (49-1400), 317 \\
\hline
\end{tabular}


medRxiv preprint doi: https://doi.org/10.1101/2021.10.05.21264462; this version posted October 7, 2021. The copyright holder for this preprint (which was not certified by peer review) is the author/funder, who has granted medRxiv a license to display the preprint in It is made available under a CC-BY-NC-ND 4.0 International license .

Table 2. Detection and quantification rates of SARS-CoV-2 RNA (N2-assay) analyzed from wastewater at 28 WWTPs in the groups of reported new COVID-19 case incidence rates in the corresponding sewer network area in Finland over a surveillance period of 10-months (3 August 2020 to 31 May 2021).

\begin{tabular}{|c|c|c|c|c|c|c|}
\hline \multicolumn{2}{|c|}{ Reported incidences $(/ \mathbf{1 0 0 , 0 0 0 )}$} & \multirow{2}{*}{$\begin{array}{c}\text { Total } \\
\text { samples } \\
\text { included }\end{array}$} & \multicolumn{2}{|c|}{ N2 assay >LOD } & \multicolumn{2}{|c|}{ N2 assay >LOQ } \\
\hline Interval & Geometric mean cases & & $\begin{array}{l}\text { No of samples } \\
\text { positive (n) }\end{array}$ & $\begin{array}{l}\text { Positive } \\
\text { rate }(\%)\end{array}$ & $\begin{array}{c}\text { No of } \\
\text { samples } \\
\text { positive }(\mathbf{n})\end{array}$ & $\begin{array}{c}\text { Positive } \\
\text { rate } \\
(\%)\end{array}$ \\
\hline 0 & 0 & 39 & 6 & 15 & 1 & 3 \\
\hline $0-2.50$ & 1.6 & 20 & 6 & 30 & 0 & 0 \\
\hline $2.5-3.64$ & 3.01 & 20 & 5 & 25 & 0 & 0 \\
\hline $3.64-4.76$ & 4.39 & 20 & 6 & 30 & 1 & 5 \\
\hline $4.76-6.67$ & 5.53 & 20 & 10 & 50 & 0 & 0 \\
\hline $6.67-8.90$ & 7.96 & 20 & 8 & 40 & 0 & 0 \\
\hline $8.90-11.64$ & 10.23 & 20 & 14 & 70 & 1 & 5 \\
\hline $11.64-14.29$ & 13.05 & 20 & 16 & 80 & 0 & 0 \\
\hline $14.29-16.39$ & 15.23 & 20 & 14 & 70 & 0 & 0 \\
\hline $16.39-17.50$ & 17.07 & 20 & 13 & 65 & 0 & 0 \\
\hline $17.50-20.47$ & 18.91 & 20 & 16 & 80 & 0 & 0 \\
\hline $20.47-22.95$ & 21.63 & 20 & 17 & 85 & 2 & 10 \\
\hline $22.95-27.17$ & 25.46 & 20 & 17 & 85 & 0 & 0 \\
\hline $27.17-30.16$ & 28.78 & 20 & 19 & 95 & 2 & 10 \\
\hline $30.16-32.79$ & 31.65 & 20 & 17 & 85 & 0 & 0 \\
\hline $32.79-38.10$ & 35.34 & 20 & 18 & 90 & 2 & 10 \\
\hline $38.10-42.42$ & 40.83 & 20 & 19 & 95 & 1 & 5 \\
\hline $42.42-47.27$ & 45.09 & 20 & 19 & 95 & 3 & 15 \\
\hline $47.27-52.38$ & 49.84 & 20 & 19 & 95 & 3 & 15 \\
\hline $52.38-57.14$ & 54.60 & 20 & 17 & 85 & 6 & 30 \\
\hline 57.14-62.86 & 59.72 & 20 & 19 & 95 & 4 & 20 \\
\hline $62.86-74.50$ & 69.67 & 20 & 20 & 100 & 5 & 25 \\
\hline $74.50-80.58$ & 77.46 & 20 & 20 & 100 & 4 & 20 \\
\hline $80.58-94.49$ & 88.12 & 20 & 20 & 100 & 7 & 35 \\
\hline $94.49-100.00$ & 96.79 & 20 & 20 & 100 & 7 & 35 \\
\hline $100.00-110.81$ & 106.82 & 20 & 20 & 100 & 9 & 45 \\
\hline $110.81-121.21$ & 116.36 & 20 & 19 & 95 & 11 & 55 \\
\hline $121.21-137.00$ & 126.47 & 20 & 20 & 100 & 13 & 65 \\
\hline $137.00-163.67$ & 149.23 & 20 & 20 & 100 & 11 & 55 \\
\hline $163.67-196.50$ & 177.96 & 20 & 20 & 100 & 15 & 75 \\
\hline $196.50-238.72$ & 220.67 & 20 & 20 & 100 & 14 & 70 \\
\hline $238.72-299.19$ & 271.32 & 20 & 20 & 100 & 15 & 75 \\
\hline $299.19-460.70$ & 356.81 & 20 & 20 & 100 & 18 & 90 \\
\hline $460.70-767.50$ & 521.05 & 14 & 14 & 100 & 10 & 71 \\
\hline
\end{tabular}


Table 3. Reported COVID-19 cases in the sewer network areas, wastewater-based SARS-CoV-2 detection and quantification rates, SARS-CoV-2 gene copies enumerated with N2-assay, and linear regression analysis of 14-day moving sum as a dependent variable and flow-corrected SARS-CoV-2 gene copies/day/100 000 persons (SARS-CoV-2), sample temperature after transport (T), and sample processing delay (D) as explaining variables in A) large and B) small WWTPs, serving population above and below 63500 inhabitants, respectively, out of the 28 WWTPs included in a 10-month national surveillance period in Finland.

\begin{tabular}{|c|c|c|c|c|c|c|c|c|c|c|c|c|}
\hline \multirow[t]{2}{*}{$\begin{array}{c}\text { WWTP } \\
\text { (Location, N) }\end{array}$} & \multicolumn{2}{|c|}{$\begin{array}{c}\text { COVID-19 incidence } \\
\text { (14-DMS / 100,000 persons) }\end{array}$} & \multirow[t]{2}{*}{$\begin{array}{l}\text { Population } \\
\text { served } \\
\text { (coverage) }\end{array}$} & \multicolumn{2}{|c|}{$\begin{array}{l}\text { SARS-CoV-2 in wastewater } \\
\text { (N2-assay) }\end{array}$} & \multicolumn{2}{|c|}{$\begin{array}{c}\text { SARS-CoV-2 copy number } \\
\text { /day/person; } \\
\text { N2-assay }\left(\log _{10}\right)\end{array}$} & \multicolumn{5}{|c|}{ Linear regression } \\
\hline & Mean \pm SE & $\begin{array}{c}\text { Median } \\
\text { (Min - Max) }\end{array}$ & & $\begin{array}{l}\text { Detection } \\
\text { rate }^{1}, \%\end{array}$ & $\begin{array}{l}\text { Quantification } \\
\quad \text { rate, } \%\end{array}$ & Mean \pm SE & $\begin{array}{c}\text { Median } \\
\text { (Min - Max) }\end{array}$ & $\begin{array}{l}\mathrm{R}^{2} \text {-value } \\
\text { (n) }\end{array}$ & $p$-value ${ }^{2}$ & $\begin{array}{l}p \text {-value } \\
\text { (SARS- } \\
\text { CoV-2) }\end{array}$ & $\begin{array}{c}p- \\
\text { value } \\
(\mathrm{T})\end{array}$ & $\begin{array}{c}p- \\
\text { value } \\
\text { (D) }\end{array}$ \\
\hline $\begin{array}{c}\text { Large WWTPs } \\
(\mathbf{N}=400)\end{array}$ & $67.5 \pm 3.9$ & $\begin{array}{c}41.6 \\
(0.0-462.4)\end{array}$ & $\begin{array}{c}2770404 \\
(0.77)\end{array}$ & $82(+6)$ & 33 & $6.2 \pm 0.1$ & $\begin{array}{c}5.5 \\
(5.2-8.3)\end{array}$ & $\begin{array}{c}0.44 \\
(364)\end{array}$ & $<0.001 *$ & $<0.001 *$ & 0.52 & 0.36 \\
\hline $\begin{array}{c}\text { Viikinmäki } \\
\text { (Helsinki, 42) }\end{array}$ & $188.5 \pm 22.2$ & $\begin{array}{c}147.2 \\
(8.4-523.7) \\
\end{array}$ & $860000(0.91)$ & $100(+0)$ & 79 & $7.39 \pm 0.05$ & $\begin{array}{c}7.38 \\
(6.92-7.98) \\
\end{array}$ & $\begin{array}{l}0.56 \\
(42)\end{array}$ & $<0.001 *$ & $<0.001 *$ & 0.12 & 0.43 \\
\hline $\begin{array}{l}\text { Suomenoja } \\
(\text { Espoo, 22) }\end{array}$ & $204.5 \pm 31.0$ & $\begin{array}{c}176.5 \\
(12.3-515.9) \\
\end{array}$ & $390000(0.84)$ & $100(+0)$ & 73 & $7.37 \pm 0.10$ & $\begin{array}{c}7.23 \\
(6.87-8.10)\end{array}$ & $\begin{array}{l}0.52 \\
(22)\end{array}$ & $<0.001 *$ & $0.018^{*}$ & 0.34 & 0.58 \\
\hline $\begin{array}{l}\text { Kakolanmäki } \\
\text { (Turku, 42) }\end{array}$ & $112.7 \pm 14.4$ & $\begin{array}{c}95.5 \\
(5.0-358.7)\end{array}$ & $300000(0.87)$ & $95(+5)$ & 48 & $7.38 \pm 0.07$ & $\begin{array}{c}7.35 \\
(6.88-8.03)\end{array}$ & $\begin{array}{l}0.40 \\
(42)\end{array}$ & $<0.001 *$ & $<0.001 *$ & 0.21 & 0.33 \\
\hline $\begin{array}{c}\text { Taskila } \\
(\text { Oulu, 41) }\end{array}$ & $50.8 \pm 7.4$ & $\begin{array}{c}40.0 \\
(1.0-198.0) \\
\end{array}$ & $200000(0.88)$ & $71(+5)$ & 17 & $7.12 \pm 0.08$ & $\begin{array}{c}7.15 \\
(6.80-7.48)\end{array}$ & $\begin{array}{l}0.40 \\
(31)\end{array}$ & $0.0011^{*}$ & $<0.001 *$ & 0.08 & $0.025^{*}$ \\
\hline $\begin{array}{l}\text { Viinikanlahti } \\
\text { (Tampere, } 41 \text { ) }\end{array}$ & $77.7 \pm 8.5$ & $\begin{array}{c}61.0 \\
(1.0-196.5) \\
\end{array}$ & $200000(0.64)$ & $88(+2)$ & 37 & $7.22 \pm 0.08$ & $\begin{array}{c}7.08 \\
(6.84-7.82)\end{array}$ & $\begin{array}{l}0.34 \\
(37)\end{array}$ & $<0.001 *$ & $<0.001^{*}$ & 0.55 & 0.099 \\
\hline $\begin{array}{c}\text { Nenäinniemi } \\
\text { (Jyväskylä, 21) }\end{array}$ & $59.5 \pm 9.8$ & $\begin{array}{c}50.5 \\
(1.3-177.2) \\
\end{array}$ & $155000(0.88)$ & $95(+5)$ & 38 & $7.34 \pm 0.16$ & $\begin{array}{c}7.34 \\
(6.80-7.98) \\
\end{array}$ & $\begin{array}{l}0.37 \\
(21)\end{array}$ & $0.012 *$ & $0.0068^{*}$ & 0.26 & 0.98 \\
\hline $\begin{array}{l}\text { Luotsinmäki } \\
\text { (Pori, 21) }\end{array}$ & $24.5 \pm 4.6$ & $\begin{array}{c}17.9 \\
(0.0-75.9)\end{array}$ & $112000(0.86)$ & $38(+19)$ & 0 & - & - & $\begin{array}{l}-0.25 \\
(12)\end{array}$ & 0.85 & 0.53 & 0.54 & 0.81 \\
\hline $\begin{array}{c}\text { Mussalo } \\
\text { (Kotka, 21) }\end{array}$ & $70.9 \pm 12.7$ & $\begin{array}{c}57.6 \\
(1.0-260.6) \\
\end{array}$ & $99000(0.60)$ & $52(+24)$ & 5 & 6.65 & - & $\begin{array}{l}0.44 \\
(16)\end{array}$ & $0.012 *$ & $0.0092 *$ & 0.84 & 0.38 \\
\hline $\begin{array}{c}\text { Kuhasalo } \\
\text { (Joensuu, 21) }\end{array}$ & $22.3 \pm 4.8$ & $\begin{array}{c}16.3 \\
(0.0-93.9) \\
\end{array}$ & $98000(0.91)$ & $66(+10)$ & 0 & - & - & $\begin{array}{l}0.68 \\
(16) \\
\end{array}$ & 0.68 & 0.66 & 0.35 & 0.71 \\
\hline $\begin{array}{l}\text { Lehtoniemi } \\
\text { (Kuopio, 42) }\end{array}$ & $37.7 \pm 6.1$ & $\begin{array}{c}25.1 \\
(0.0-173.1)\end{array}$ & $91000(0.76)$ & $74(+7)$ & 17 & $7.23 \pm 0.12$ & $\begin{array}{c}7.14 \\
(6.88-7.94)\end{array}$ & $\begin{array}{l}0.22 \\
(34)\end{array}$ & $0.015^{*}$ & $0.016^{*}$ & 0.49 & 0.084 \\
\hline $\begin{array}{c}\text { Pått } \\
(\text { Vaasa, 22) }\end{array}$ & $108.0 \pm 31.1$ & $\begin{array}{c}50.4 \\
(2.9-615.8) \\
\end{array}$ & $70000(0.75)$ & $86(+9)$ & 18 & $7.47 \pm 0.16$ & $\begin{array}{c}7.52 \\
(7.03-7.82) \\
\end{array}$ & $\begin{array}{l}0.78 \\
(21)\end{array}$ & $<0.001 *$ & $<0.001^{*}$ & 0.61 & 0.24 \\
\hline $\begin{array}{c}\text { Mäkikylä } \\
\text { (Kouvola, 22) }\end{array}$ & $49.7 \pm 7.7$ & $\begin{array}{c}46.9 \\
(0.0-113.3) \\
\end{array}$ & $67000(0.82)$ & $73(+18)$ & 9 & $7.26 \pm 0.02$ & $\begin{array}{c}7.26 \\
(7.22-7.29)\end{array}$ & $\begin{array}{l}0.11 \\
(20)\end{array}$ & 0.20 & 0.52 & 0.42 & 0.092 \\
\hline $\begin{array}{c}\text { Paroinen } \\
\text { (Hämeenlinna, 21) }\end{array}$ & $62.8 \pm 10.4$ & $\begin{array}{c}53.0 \\
(0.0-207.6)\end{array}$ & $66000(0.46)$ & $95(+0)$ & 52 & $7.26 \pm 0.11$ & $\begin{array}{c}7.18 \\
(6.74-7.94)\end{array}$ & $\begin{array}{l}-0.12 \\
(19)\end{array}$ & 0.64 & 0.22 & 0.63 & 0.80 \\
\hline $\begin{array}{c}\text { Kariniemi } \\
\text { (Lahti I, 21) }\end{array}$ & $175.6 \pm 33.6$ & $\begin{array}{c}97.6 \\
(0.0-483.5)\end{array}$ & $64000(0.44)$ & $81(+5)$ & 29 & $7.67 \pm 0.19$ & $\begin{array}{c}7.74 \\
(6.91-8.34)\end{array}$ & $\begin{array}{l}0.48 \\
(18)\end{array}$ & $0.0065^{*}$ & $0.0019 *$ & 0.63 & 0.33 \\
\hline
\end{tabular}




\begin{tabular}{|c|c|c|c|c|c|c|c|c|c|c|c|c|}
\hline $\begin{array}{l}\text { Small WWTPs } \\
(N=293)\end{array}$ & $44.7 \pm 4.1$ & $\begin{array}{c}20.9 \\
(0-632.9)\end{array}$ & 535785 (0.78) & $62(+5)$ & 12 & $5.8 \pm 0.1$ & $\begin{array}{c}5.5 \\
(5.2-8.7)\end{array}$ & $\begin{array}{c}0.23 \\
(182)\end{array}$ & $<0.001 *$ & $<0.001 *$ & 0.18 & 0.49 \\
\hline $\begin{array}{c}\text { Toikansuo } \\
\text { (Lappeenranta, 21) }\end{array}$ & $62.2 \pm 17.6$ & $\begin{array}{c}30.2 \\
(0.0-285.7)\end{array}$ & $63000(0.78)$ & $66(+10)$ & 5 & 7.53 & - & $\begin{array}{l}0.36 \\
(16)\end{array}$ & $0.038 *$ & $0.0097 *$ & 0.59 & 0.64 \\
\hline $\begin{array}{c}\text { Ali-Juhakkala } \\
(\text { Lahti II, 21) }\end{array}$ & $181.3 \pm 34.7$ & $\begin{array}{c}100.8 \\
(0.0-499.2)\end{array}$ & $62000(0.43)$ & $86(+5)$ & 33 & $7.32 \pm 0.16$ & $\begin{array}{c}7.45 \\
(6.77-8.07)\end{array}$ & $\begin{array}{l}0.18 \\
(19)\end{array}$ & 0.11 & $0.020 *$ & 0.92 & 0.62 \\
\hline $\begin{array}{c}\text { Alakorkalo } \\
\text { (Rovaniemi, 21) }\end{array}$ & $22.7 \pm 4.0$ & $\begin{array}{c}27.3 \\
(1.8-72.7) \\
\end{array}$ & $55000(0.87)$ & $57(+0)$ & 0 & - & - & $\begin{array}{l}0.32 \\
(12)\end{array}$ & 0.11 & 0.27 & 0.18 & 0.12 \\
\hline $\begin{array}{c}\text { Keskuspuhdistamo } \\
(\text { Salo, 21) }\end{array}$ & $83.5 \pm 17.8$ & $\begin{array}{c}66.7 \\
(0.0-255.6) \\
\end{array}$ & $45000(0.86)$ & $71(+0)$ & 19 & $7.89 \pm 0.40$ & $\begin{array}{c}8.11 \\
(6.62-8.72) \\
\end{array}$ & $\begin{array}{l}0.38 \\
(15)\end{array}$ & 0.052 & $0.013 *$ & 0.06 & 0.72 \\
\hline $\begin{array}{c}\text { Keskuspuhdistamo } \\
\text { (Seinäjoki, 21) }\end{array}$ & $28.9 \pm 4.6$ & $\begin{array}{c}26.7 \\
(2.2-75.6) \\
\end{array}$ & $45000(0.87)$ & $43(+14)$ & 0 & - & - & $\begin{array}{l}0.11 \\
(12)\end{array}$ & 0.30 & 0.088 & 0.49 & 0.89 \\
\hline $\begin{array}{c}\text { Kenkäveronniemi } \\
(\text { Mikkeli, 20) }\end{array}$ & $65.8 \pm 14.0$ & $\begin{array}{c}45.2 \\
(2.4-216.7) \\
\end{array}$ & $42000(0.79)$ & $80(+5)$ & 20 & $7.23 \pm 0.19$ & $\begin{array}{c}7.21 \\
(6.77-7.72) \\
\end{array}$ & $\begin{array}{l}0.34 \\
(17) \\
\end{array}$ & $0.039 *$ & $0.017 *$ & 0.31 & 0.31 \\
\hline $\begin{array}{c}\text { Maanpäänniemi } \\
(\text { Rauma }, 21)\end{array}$ & $95.7 \pm 39.9$ & $\begin{array}{c}25.0 \\
(0.0-767.5) \\
\end{array}$ & $40000(0.82)$ & $66(+5)$ & 14 & $7.33 \pm 0.24$ & $\begin{array}{c}7.12 \\
(6.97-7.90) \\
\end{array}$ & $\begin{array}{l}0.37 \\
(15)\end{array}$ & $0.046 *$ & $0.0068 *$ & 0.60 & 0.93 \\
\hline $\begin{array}{c}\text { Hopeakivenlahti } \\
\text { (Kokkola, 21) }\end{array}$ & $32.1 \pm 13.7$ & $\begin{array}{c}13.9 \\
(0.0-294.4) \\
\end{array}$ & $36000(0.75)$ & $33(+5)$ & 10 & $7.29 \pm 0.05$ & $\begin{array}{c}7.29 \\
(7.22-7.36) \\
\end{array}$ & $0.61(8)$ & 0.086 & $0.033 *$ & 0.40 & 0.89 \\
\hline $\begin{array}{c}\text { Peuraniemi } \\
\text { (Kajaani, 21) } \\
\end{array}$ & $16.4 \pm 3.8$ & $\begin{array}{c}8.9 \\
(0.0-53.4) \\
\end{array}$ & $34000(0.92)$ & $57(+10)$ & 5 & 7.13 & - & $\begin{array}{c}-0.02 \\
(14) \\
\end{array}$ & 0.48 & 0.21 & 0.65 & 0.77 \\
\hline $\begin{array}{c}\text { Alheda } \\
\text { (Pietarsaari, 22) }\end{array}$ & $33.1 \pm 7.0$ & $\begin{array}{c}21.3 \\
(0.0-124.6) \\
\end{array}$ & $32000(0.70)$ & $64(+0)$ & 9 & $7.15 \pm 0.13$ & $\begin{array}{c}7.15 \\
(6.97-7.33) \\
\end{array}$ & $\begin{array}{l}0.10 \\
(14)\end{array}$ & 0.28 & 0.14 & 0.41 & 0.84 \\
\hline $\begin{array}{l}\text { Peurasaari } \\
(\text { Kemi, 21) }\end{array}$ & $15.7 \pm 4.0$ & $\begin{array}{c}8.7 \\
(0.0-69.6) \\
\end{array}$ & $23000(0.97)$ & $23(+10)$ & 0 & - & - & $0.42(7)$ & 0.24 & 0.30 & 0.58 & 0.57 \\
\hline $\begin{array}{c}\text { Pihlajaniemi } \\
\text { (Savonlinna, 21) }\end{array}$ & $56.0 \pm 20.2$ & $\begin{array}{c}17.7 \\
(0.0-336.3) \\
\end{array}$ & $23000(0.68)$ & $52(+5)$ & 10 & $7.19 \pm 0.09$ & $\begin{array}{c}7.19 \\
(7.06-7.32) \\
\end{array}$ & $\begin{array}{l}0.01 \\
(12)\end{array}$ & 0.43 & 0.16 & 0.68 & 0.69 \\
\hline $\begin{array}{c}\text { Lotsbroverket } \\
\text { (Maarianhamina, } \\
\text { 21) }\end{array}$ & $69.2 \pm 26.5$ & $\begin{array}{c}19.0 \\
(0.0-523.8)\end{array}$ & $21000(0.81)$ & $81(+0)$ & 14 & $7.21 \pm 0.09$ & $\begin{array}{c}7.24 \\
(7.01-7.39)\end{array}$ & $\begin{array}{l}0.56 \\
(17)\end{array}$ & $0.0012 *$ & $<0.001 *$ & 0.16 & $N D$ \\
\hline $\begin{array}{l}\text { Nummela } \\
\text { (Vihti, 20) }\end{array}$ & $111.4 \pm 22.2$ & $\begin{array}{c}94.3 \\
(0.0-394.3) \\
\end{array}$ & $18000(0.60)$ & $90(+0)$ & 30 & $7.72 \pm 0.23$ & $\begin{array}{c}7.60 \\
(6.87-8.66) \\
\end{array}$ & $\begin{array}{l}0.74 \\
(18) \\
\end{array}$ & 0.74 & 0.92 & 0.43 & 0.64 \\
\hline $\begin{array}{c}\text { Total mean } \\
(\mathrm{N}=693)\end{array}$ & $78.5 \pm 4.0$ & $\begin{array}{c}40.4 \\
(0.0-767.5) \\
\end{array}$ & $\begin{array}{c}3300000 \\
(0.77) \\
\end{array}$ & $73(+6)$ & 24 & $7.35 \pm 0.03$ & $\begin{array}{c}7.29 \\
(6.62-8.72) \\
\end{array}$ & $\begin{array}{c}0.36 \\
(547) \\
\end{array}$ & $<0.001 *$ & $<0.001 *$ & 0.71 & 0.09 \\
\hline $\begin{array}{l}\text { Mean }(p<0.05) \\
\quad(\mathrm{N}=440)\end{array}$ & $70.6 \pm 4.1$ & $\begin{array}{c}40.5 \\
(0.0-632.7) \\
\end{array}$ & $\begin{array}{c}2676000 \\
(0.77)\end{array}$ & $80(+5)$ & 30 & $6.15 \pm 0.06$ & $\begin{array}{c}5.50 \\
(5.21-8.72)\end{array}$ & NA & NA & NA & NA & NA \\
\hline $\begin{array}{c}\text { Mean }(p>0.05) \\
(\mathrm{N}=253)\end{array}$ & $35.8 \pm 2.8$ & $\begin{array}{c}21.4 \\
(0.0-236.6) \\
\end{array}$ & $635000(0.77)$ & $62(+8)$ & 12 & $5.81 \pm 0.06$ & $\begin{array}{c}5.47 \\
(5.17-8.66) \\
\end{array}$ & NA & NA & NA & NA & NA \\
\hline
\end{tabular}


medRxiv preprint doi: https://doi.org/10.1101/2021.10.05.21264462; this version posted October 7, 2021. The copyright holder for this preprint (which was not certified by peer review) is the author/funder, who has granted medRxiv a license to display the preprint in It is made available under a CC-BY-NC-ND 4.0 International license .

Figure 1. Total daily reported COVID-19 cases in the municipalities covered in the national wastewater sample collection.

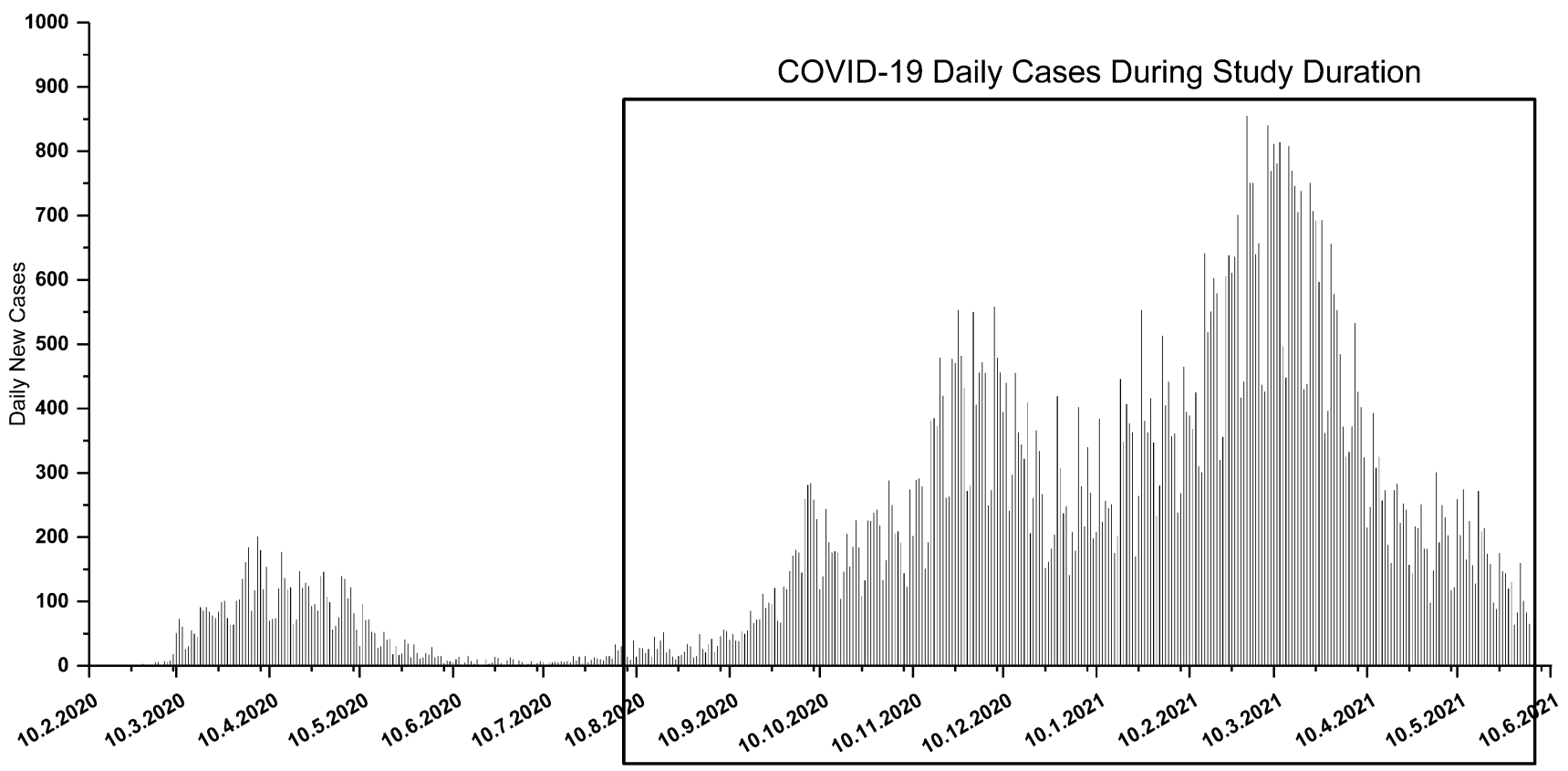

Figure 2. Relationship between COVID-19 incidence and the detection and quantification rates of SARSCoV-2 RNA determined using N2-assay in wastewater.

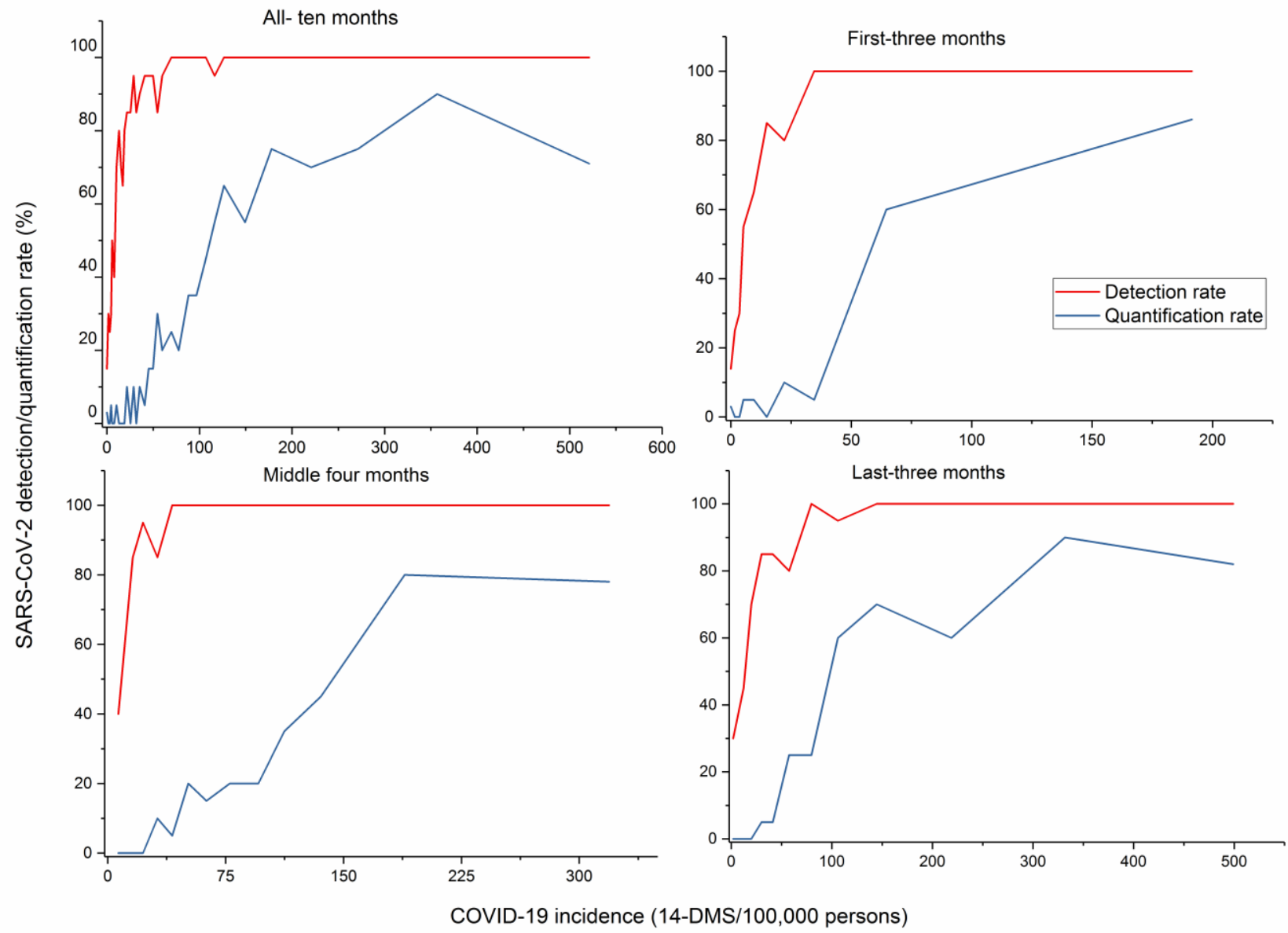


medRxiv preprint doi: https://doi.org/10.1101/2021.10.05.21264462; this version posted October 7, 2021. The copyright holder for this preprint (which was not certified by peer review) is the author/funder, who has granted medRxiv a license to display the preprint in It is made available under a CC-BY-NC-ND 4.0 International license .

Figure 3. Fourteen-day COVID-19 incidence rate thresholds in the sewer network area covered by national surveillance in Finland required for wastewater-based SARS-CoV-2 detection and quantification estimated with logistic regression.
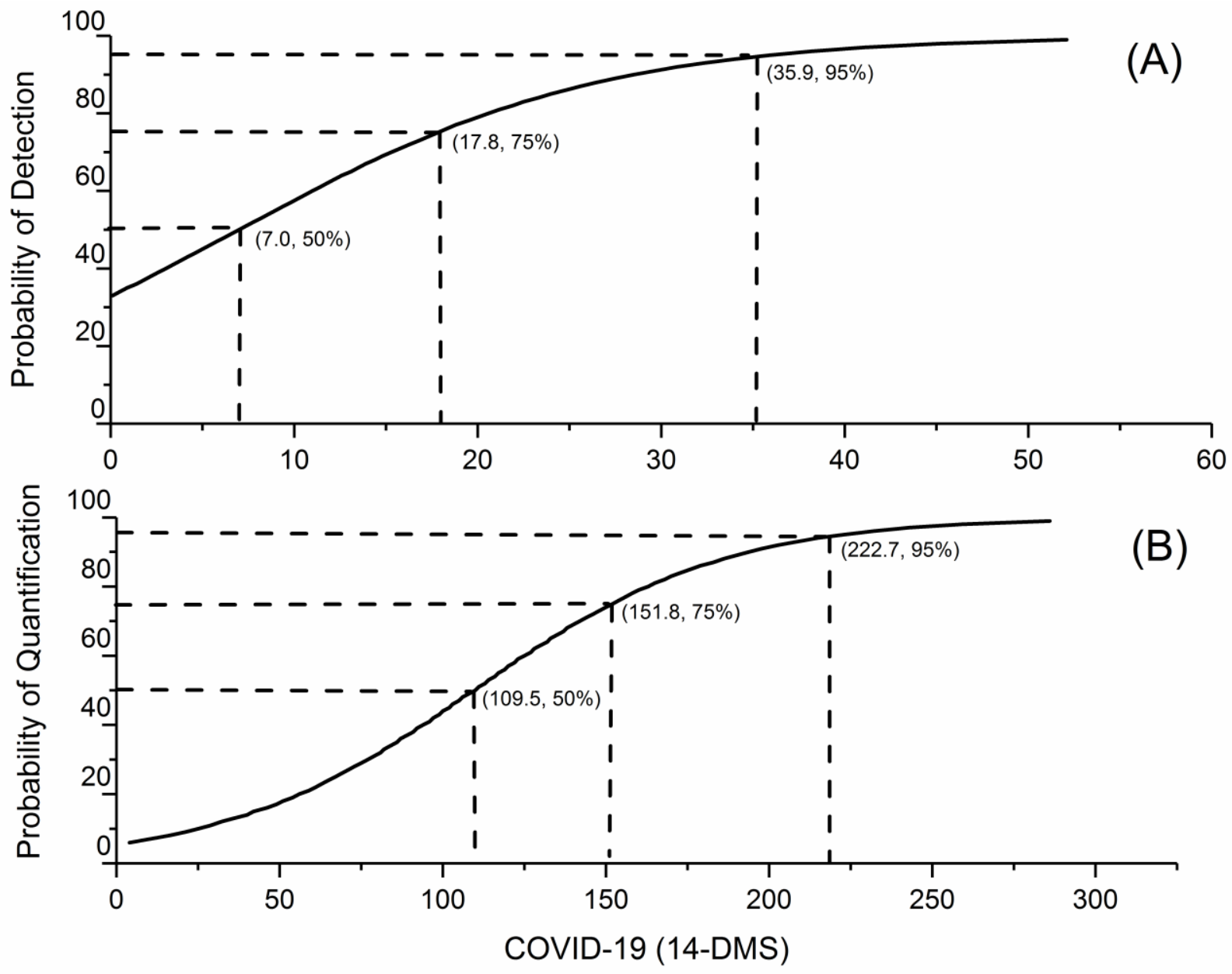
medRxiv preprint doi: https://doi.org/10.1101/2021.10.05.21264462; this version posted October 7, 2021. The copyright holder for this preprint (which was not certified by peer review) is the author/funder, who has granted medRxiv a license to display the preprint in It is made available under a CC-BY-NC-ND 4.0 International license .

Figure 4. The trend of SARS-CoV-2 RNA (GC/day/person) in WW samples and COVID-19 incidence (per 100000 persons). Sample dots with (-) denote SARS-CoV-2 was not detected, (+) denotes that the detection was uncertain, (*) denotes detected, but below quantification limit (LOQ). A) City areas (Helsinki, Espoo, Turku, Hämeenlinna) with quantification rate (QR) 48-79\%. B) City areas (Jyväskylä, Tampere, Lahti II, Vihti) with QR 30-38\%. C) City areas (Mikkeli, Lahti I, Salo, Vaasa) with QR 18-29\%. D) City areas (Kuopio, Oulu, Rauma, Maarianhamina) with QR 14-17\%. E) City areas (Kokkola, Kouvola, Pietarsaari, Savonlinna) with QR 9-10\%. F) City areas (Kajaani, Kotka, Pori, Lappeenranta) with QR 0-5\%. G) City areas (Rovaniemi, Joensuu, Kemi, Seinäjoki) with QR 0\%. Caution: the Y-axis of each graph is different, and the $\mathrm{x}$-axis is the same. Samples with arrival temperature higher than $15^{\circ} \mathrm{C}(\mathrm{C})$ and transportation delay more than or equal to three days (D) are shown.
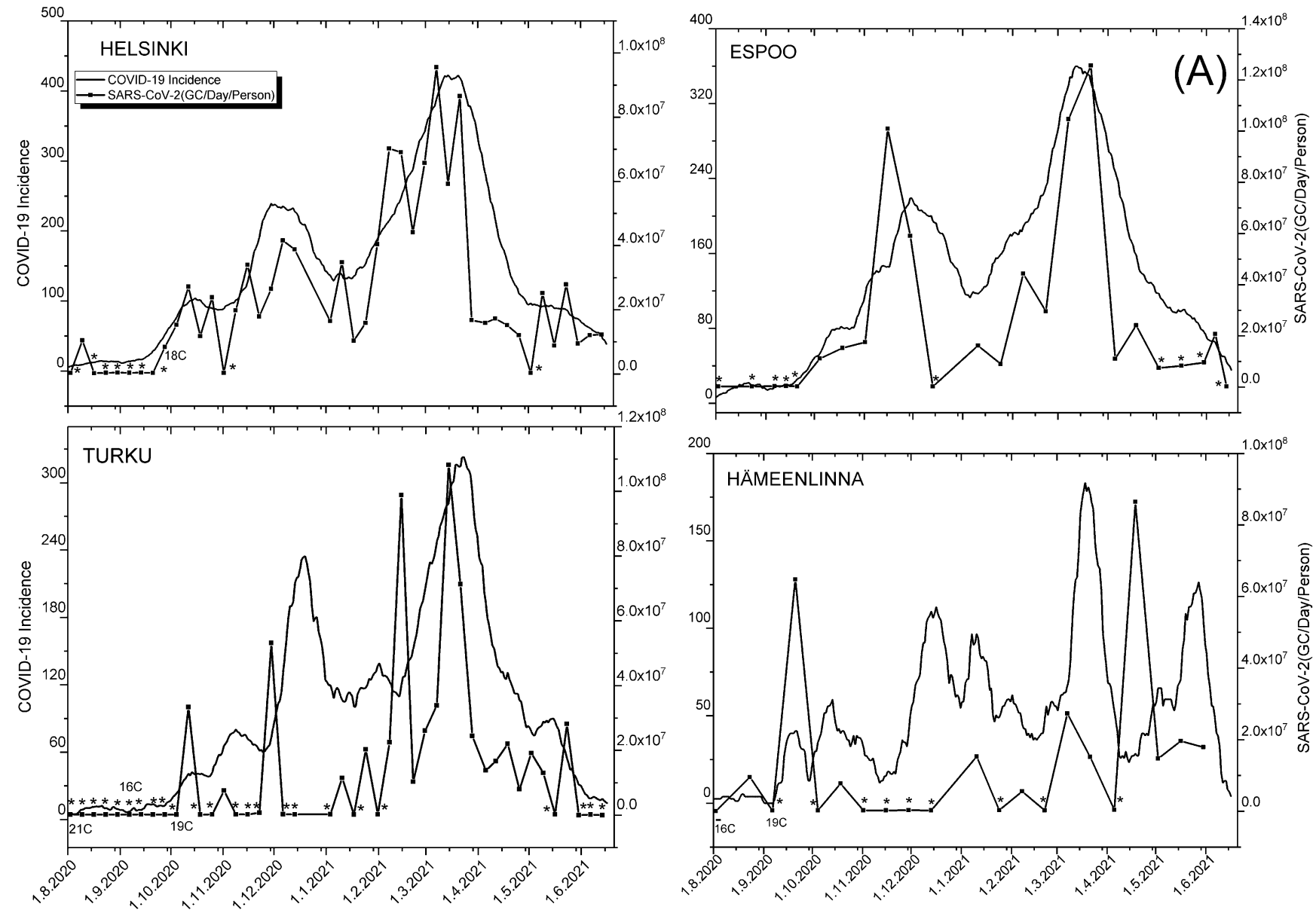
medRxiv preprint doi: https://doi.org/10.1101/2021.10.05.21264462; this version posted October 7, 2021. The copyright holder for this preprint (which was not certified by peer review) is the author/funder, who has granted medRxiv a license to display the preprint in It is made available under a CC-BY-NC-ND 4.0 International license .
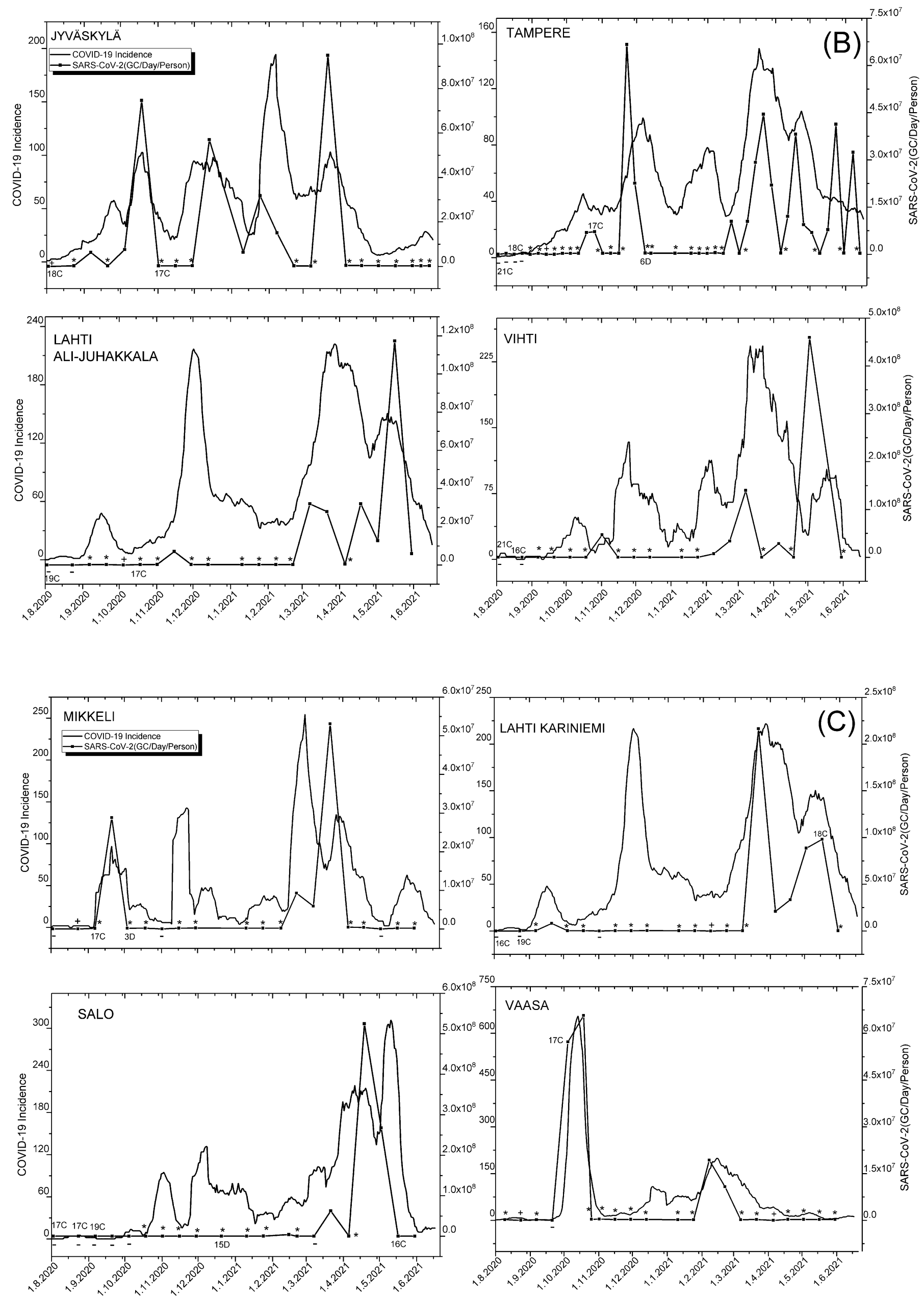
medRxiv preprint doi: https://doi.org/10.1101/2021.10.05.21264462; this version posted October 7, 2021. The copyright holder for this preprint (which was not certified by peer review) is the author/funder, who has granted medRxiv a license to display the preprint in It is made available under a CC-BY-NC-ND 4.0 International license .
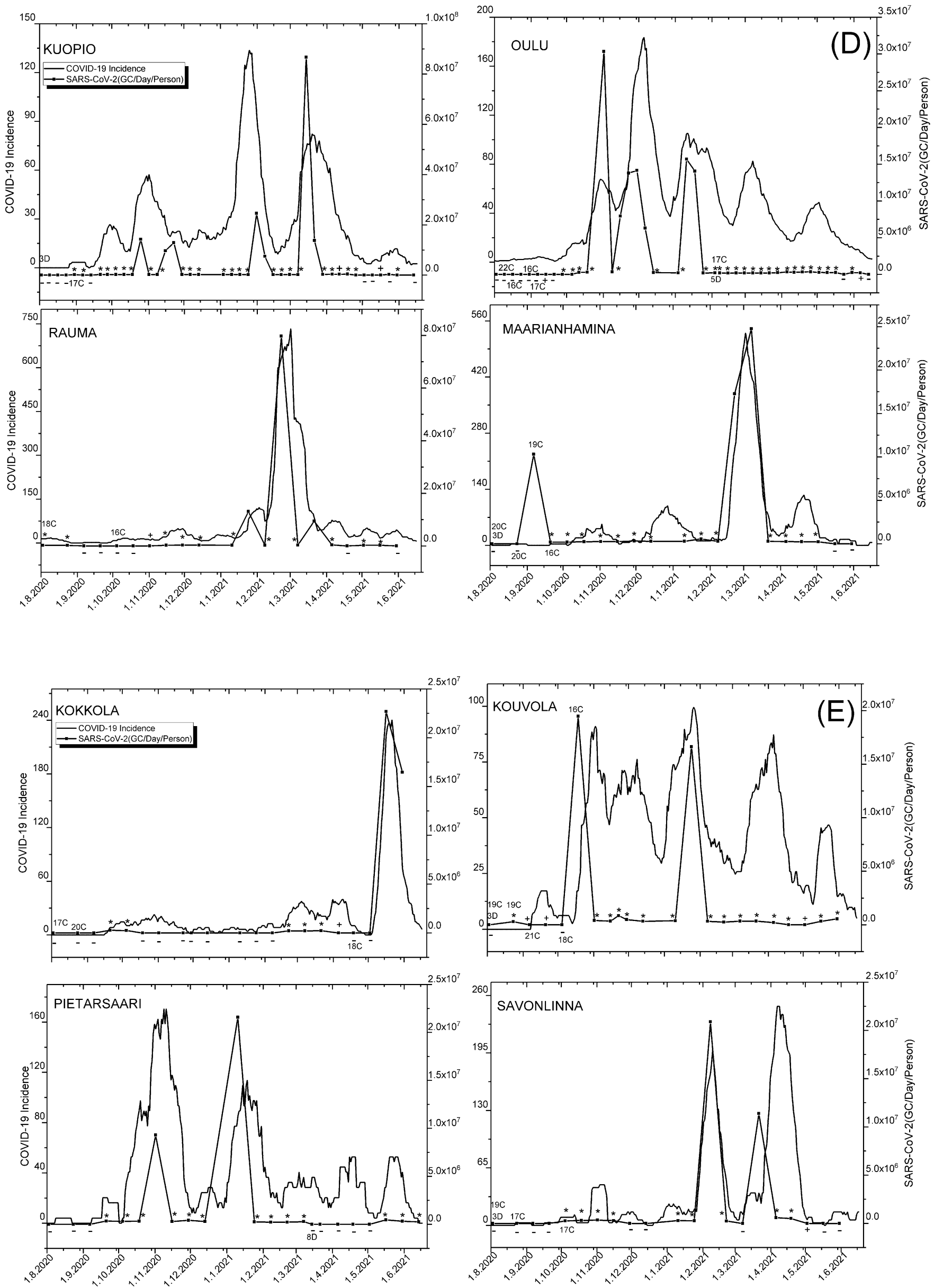
medRxiv preprint doi: https://doi.org/10.1101/2021.10.05.21264462; this version posted October 7, 2021. The copyright holder for this preprint (which was not certified by peer review) is the author/funder, who has granted medRxiv a license to display the preprint in It is made available under a CC-BY-NC-ND 4.0 International license .
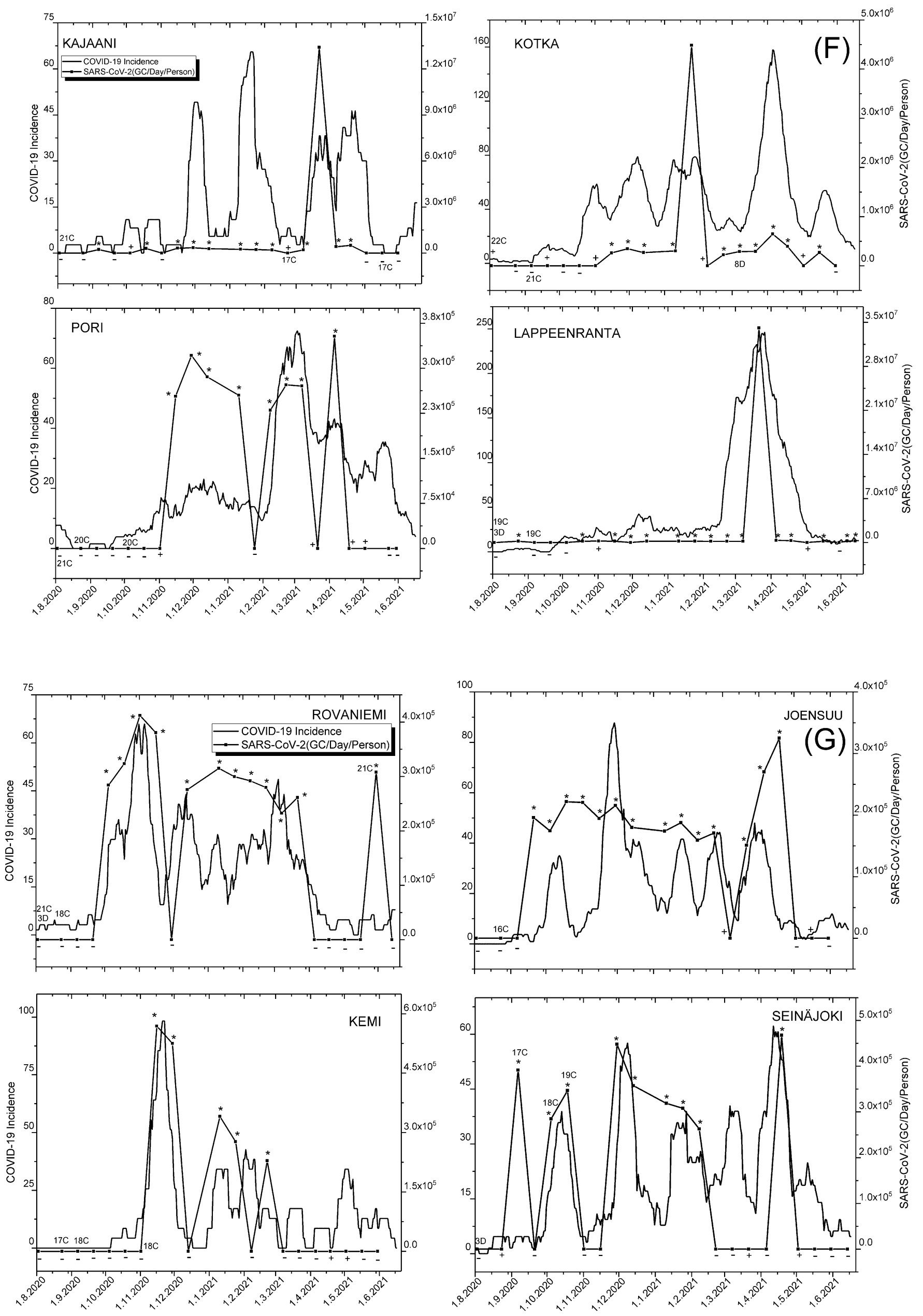